\title{
Growth Kinetics and Ganoderic Acid Production from Ganoderma lucidum GIRAN17: A Real-Time Monitoring Platform
}

\author{
Motaharehsadat Heydarian ${ }^{1,2}$, Ashrafalsadat Hatamian-Zarmi ${ }^{1 *}$, Ghassem Amoabediny ${ }^{2,3}$ \\ Bahman Ebrahimi Hoseinzadeh ${ }^{1}$, Hale Alvandi ${ }^{1}$, Ali Doryab ${ }^{1,2}$, Amir Salehi ${ }^{4}$
}

1. Department of Life Science Engineering, Faculty of New Sciences and Technologies, University of Tehran, Tehran, Iran

2. Research Center for New Technologies in Life Science Engineering, University of Tehran, Tehran, Iran

3. Department of Chemical Engineering, Faculty of Engineering, University of Tehran, Tehran, Iran

4. Department of Microbiology, School of Biology, College of Science, University of Tehran, Tehran, Iran

\section{ABSTRACT}

Background: Ganoderma lucidum is a traditional medicinal mushroom that has many therapeutic applications. However, the application of this beneficial fungus has been limited due to its secondary metabolite's low production. Many investigations have been carried out to improve the production of G. lucidum as well as Ganoderic Acid (GA); however, prior studies suffer from the lack of sufficient monitoring platform. A real-time monitoring study could be useful to find more information through cultivation and evaluating secondary metabolite production.

Materials and Methods: In the current study, aerated shaken flasks (AF) with different culture mediums were used for online measurement of the respiration activity of $G$. lucidum in small scale bioreactors. Then, to find more information through G. lucidum growth, four factors, including biomass formation, GA, residual sugar, and gene expression were evaluated on different days.

Results: Online monitoring of cell proliferation demonstrated that GA starts to synthesize in the second growth phase as a partially growth-associated metabolite. High maximum biomass and GA production were obtained at an initial glucose concentration of $35 \mathrm{~g} / \mathrm{L}$ with vitamin and $\mathrm{KH}_{2} \mathrm{PO}_{4}$. During fermentation, the $\mathrm{Y}_{\mathrm{O} 2 / \mathrm{GA}}$ and $\mathrm{Y}_{\mathrm{O} 2 / \mathrm{X}}$ the rate of oxygen consumption rate per GA production and biomass formation, respectively, were introduced as beneficial parameters to scale-up the process.

Conclusions: A novel monitoring strategy was suggested which can be beneficial for future investigations.

Keywords: Ganoderma lucidum, Monitoring, Growth kinetics, Oxygen transfer rate, Miniaturized bioreactor

Received: 2020/02/29; $\quad$ Accepted: 2020/12/06; Published Online: 2021/01/10

\begin{tabular}{|c|c|}
\hline Corresponding Information: & $\begin{array}{l}\text { Ashrafalsadat Hatamian-Zarmi, Department of Life Science Engineering, Faculty of New Sciences and Technologies, University of } \\
\text { Tehran, Tehran, Iran. Email: hatamian a@ } @ \text { ut.ac.ir }\end{array}$ \\
\hline (c) $\underset{\mathrm{BY}}{(\mathrm{i})}$ & $\begin{array}{l}\text { This is an original open-access article distributed under the terms of the Creative Commons Attribution-noncommercial } 4.0 \text { International License which } \\
\text { edistribution of the material just in noncommercial usages with proper citation. }\end{array}$ \\
\hline
\end{tabular}

Use your device to scan and read the article online

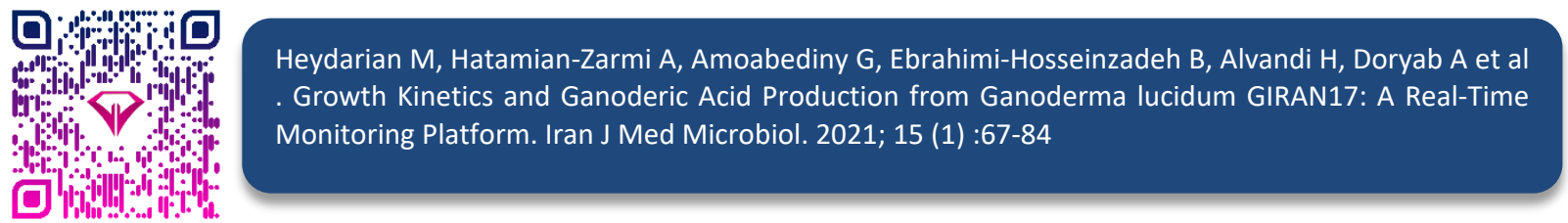

Download citation: BibTeX | RIS | EndNote | Medlars | ProCite | Reference Manager | RefWorks
Send citation to:
8 Mendeley
(2) zotero
RefWorks

\section{Introduction}

Ganoderma lucidum is widely used in Asia to treat health problems and increase vitality and longevity. These mushrooms offer various health benefits, including immunomodulatory, antitumor, antibacterial, antiviral, anti-diabetic, and anti-oxidant properties [1, 2]. Ganoderic Acid (GA) is a type of 
triterpenoids produced by $G$. lucidum and is considered a secondary metabolite [3]. Some GAs can inhibit cholesterol synthesis and tumor growth, which can effectively cure cancer $[4,5]$. However, due to the low efficacy of GA production from $G$. lucidum, these useful metabolite applications have been limited.

Therefore, investigations are growing to enhance the GA biosynthesis' efficiency by evaluating diverse conditions, in desired parameters such as $\mathrm{pH}$, oxygen pressure and shear stress [6-8]. Furthermore, several studies have been performed to find suitable culture media for optimizing the production of mycelial biomass and secondary metabolite. Although available studies suggests that the more complex media are superior in cell growth and production of secondary metabolites compared to other media, such as semi-synthetic [9], further research is needed to improve the efficacy of production. It has also been reported that the biomass and secondary metabolite yields are increased by improving the oxygen supply $[10,11]$. On the other hand, before scale-up studies, the traditional cultivation process has required the screening of large numbers of samples, and consequently, a vast number of development cultivations should be performed. So far, many investigations have been done to enhance G. lucidum production; however, in all of these studies, the lack of an efficient monitoring system is apparent. In fact, we can find useful information through the cultivation and obtain the necessary data for process development by monitoring the procedure. Several small-scale platforms have been developed for high throughput screening and process development.

Nevertheless, one of the most efficient and useful platforms is miniaturized bioreactors. They are widely used as tools for drug screening and discovery, optimization of media, strain, and production [12]. Miniaturized shaken bioreactor systems are also applied to measure the Oxygen Transfer Rate (OTR) during fermentation. OTR is an essential factor in obtaining more data by culturing the strains [13].

In the present work, for the first time, online and offline monitoring using miniaturized bioreactors was used for $G$. lucidum production concurrently as well as $\mathrm{GA}$ biosynthesis. Many different media were used in earlier studies; however, we tried to evaluate their different components in this study.

Moreover we examined the effects of these media on the growth of $G$. lucidum, level of oxygen consumption, and GA production. In practice, $G$. lucidum and secondary metabolite production's growth behavior using a miniaturized shaken bioreactor system suggested the best culture medium for maximal production of GA. These data are so beneficial for find a better idea to increase G. lucidum yields, and it would suggest solutions for challenges.

\section{Materials and Methods}

\section{Strains and Cultural Conditions}

G. Iucidum (Sp. GIRAN17) was obtained from bioscience faculty, Shahid Beheshti University, Tehran, Iran. It has been screened from Carpinus betulus $L$. (Corylaceae) from Mazandaran, Iran [14, 15]. The strain of $G$. lucidum was cultured on potato dextrose agar (PDA) plates according to prior study [16]. The optimum conditions for this fungus growth were temperature $\left(25^{\circ} \mathrm{C}\right)$, aeration $(130 \mathrm{rpm})$, and initial $\mathrm{pH}$ (6.5). Due to the effect of media $\mathrm{pH}$ on the stability of GA production and cell growth, the $\mathrm{pH}$ of media was kept constant during cultivation.

Studies show that high concentrations of primary glucose lead to increased biomass production and GA biosynthesis [17]. Adding vitamin B1 to the culture medium also increases productivity [18]. The aerated shaken flasks (online) and ventilation flasks (offline) included $20 \mathrm{~mL}$ broth culture [15, 17]. Four broth culture media were chosen to evaluate the growth kinetics of G. lucidum (Table 1), and inoculum size was $10 \% \mathrm{v} / \mathrm{v}$ for each broth flasks. In addition to online monitoring of the OTR during cultivation, we performed offline monitoring to measure biomass formation, residual sugar, and GA production using parallel flasks in given intervals during the fermentation time course. All the conditions of the online and offline flasks for each broth culture were kept constant.

\section{The Miniaturized Shaken Bioreactor System}

For online measurement of the respiration activity of $G$. lucidum in small scales bioreactors, aerated shaken flasks (AF) were used (Figure 1A). In this modified $250 \mathrm{ml}$ Erlenmeyer flasks, all of the conditions except the culture medium were the same [19]. Each AF contained a different culture medium: $\mathrm{AF}_{1}$ contained $\mathrm{PDB}$ (basal medium), $\mathrm{AF}_{2}$ contained $\mathrm{PDB}$ and vitamin $B_{1}, A F_{3}$ contained $Y P G$, and $A F_{4}$ contained complex media (Table 1). Briefly, on-line monitoring based on OTR was performed and the partial pressures were monitored using an oxygen sensor. The OTR was calculated by the following equation:

$$
O T R=\frac{\Delta \mathrm{pO}_{2}}{\Delta \mathrm{t}} \frac{V_{G}}{R T V_{L}}
$$

Equation 1

Where $\Delta \mathrm{pO}_{2}$ is a difference of oxygen partial pressure $(\mathrm{Pa}), \mathrm{V}_{\mathrm{G}}$ is the gas volume $(\mathrm{L}), \mathrm{V}_{\mathrm{L}}$ is the liquid volume (L), $R$ is gas constant (L.Pa/K.mol), $T$ is the temperature $(\mathrm{K})$, and $\Delta \mathrm{t}$ is the time of the measuring phase (h). 
Table 1. Operating conditions of aerated shaken flasks

\begin{tabular}{|c|c|c|c|c|c|}
\hline $\begin{array}{c}\text { Flask } \\
\text { Number } \\
(\mathrm{AF} \text { and VF) }\end{array}$ & Culture medium & $\begin{array}{l}\text { Working } \\
\text { volume } \\
(\mathrm{mL})\end{array}$ & $\begin{array}{l}\text { Gas } \\
\text { volume } \\
(\mathrm{mL})\end{array}$ & $\begin{array}{l}\text { Flask } \\
\text { volume } \\
(\mathrm{mL})\end{array}$ & $\begin{array}{l}\text { Flow rate } \\
\text { (L/h) }\end{array}$ \\
\hline 1 & Potato dextrose broth (PDB) & 20 & 240 & 260 & 1.2 \\
\hline 2 & $\mathrm{PDB}+0.05 \mathrm{~g} / \mathrm{L}$ vitamin $\mathrm{B}_{1}$ & 20 & 240 & 260 & 1.2 \\
\hline 3 & $\begin{array}{c}\text { Yeast extract } 2.5 \mathrm{~g} / \mathrm{L} \text {, peptone } 5 \mathrm{~g} / \mathrm{L} \text { and glucose } 35 \mathrm{~g} / \mathrm{L} \\
\text { (YPG). }\end{array}$ & 20 & 240 & 260 & 1.2 \\
\hline 4 & $\begin{array}{c}\text { Complex media (glucose } 35 \mathrm{~g} / \mathrm{L} \text {, peptone } 5 \mathrm{~g} / \mathrm{L} \text {, yeast extract } \\
2.5 \mathrm{~g} / \mathrm{L}, \mathrm{KH}_{2} \mathrm{PO}_{4} \cdot \mathrm{H}_{2} \mathrm{O} 1 \mathrm{~g} / \mathrm{L}, \mathrm{MgSO}_{4} \cdot 7 \mathrm{H}_{2} \mathrm{O} 0.5 \mathrm{~g} / \mathrm{L} \text {, and } \\
\text { vitamin } \mathrm{B} 10.05 \mathrm{~g} / \mathrm{L} \text { ) }\end{array}$ & 20 & 240 & 260 & 1.2 \\
\hline
\end{tabular}

$250 \mathrm{~mL}$ Erlenmeyer shake flasks, called ventilation flasks (VF), were also cultivated simultaneously under the same condition as used in the aerated shaken flasks system [20]. There are several VFs that have different gas transfer resistance of the sterile closure as described and modeled [21]. Since the aeration value of online monitoring flasks or $A F$ is $1.2 \mathrm{vvm}, \mathrm{VF}$ type (diameter, $\mathrm{D}=2.80 \mathrm{~cm}$; height, $\mathrm{H}=2.12 \mathrm{~cm}$ ) was used for offline monitoring which has the same aeration value as AFs (Figure 1). Equations 2 and 3 relate the Oxygen Transfer Rate of the plug (OTR plug) and the gas transfer coefficient $\left(k_{\text {plug }}\right)$ in VF where $V_{L}$ is the filling volume, $\mathrm{P}_{\mathrm{abs}}$ is the absolute pressure, $\mathrm{P}_{\mathrm{O} 2}$ is oxygen partial pressure in headspace of the flask, $\mathrm{P}_{\mathrm{O} \text {,out }}$ is oxygen partial pressure in the surrounding environment and $\mathrm{a}, \mathrm{b}$ and $\mathrm{c}$ are fitting parameters (dimensionless) of Eq.3.

$$
O T R_{\text {plug }}=k_{\text {plug }} \cdot\left(1 / V_{L} \cdot p_{a b s}\right) \cdot\left(p O_{2, \text { out }}-p O_{2}\right)
$$

Equation 2

$$
k_{\text {plug }}=\frac{a \cdot O T R_{\text {plug }}}{b+O T R_{\text {plug }}+\frac{O T R_{\text {plug }}^{2}}{c}}
$$

for VF type 1; a : $22.4 \times 10^{6}$, b: $6.95 \times 10^{3}$, c: 19.97 [21] Therefore, to find more information through $G$. lucidum growth, four factors, including biomass formation, GA, residual sugar, and gene expression were evaluated on days $0,2,4,6,8,9,11,13$, and 14 by 35 pcs of VFs. Each run was performed at $130 \mathrm{rpm}$ and the temperature was set at $25^{\circ} \mathrm{C}$ for fourteen days.

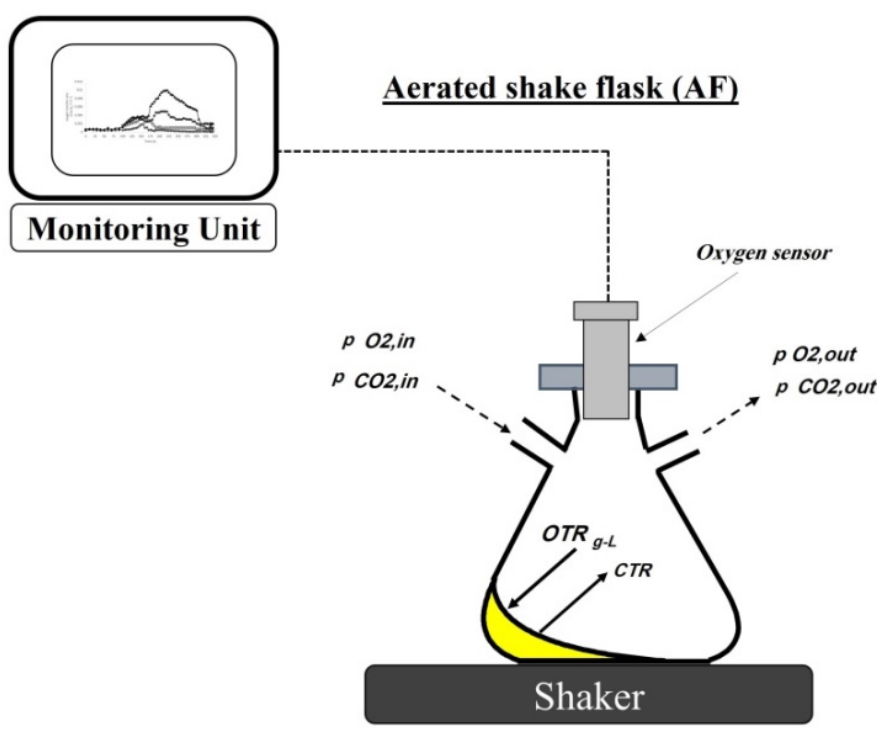

A
Ventilation flask (VF)

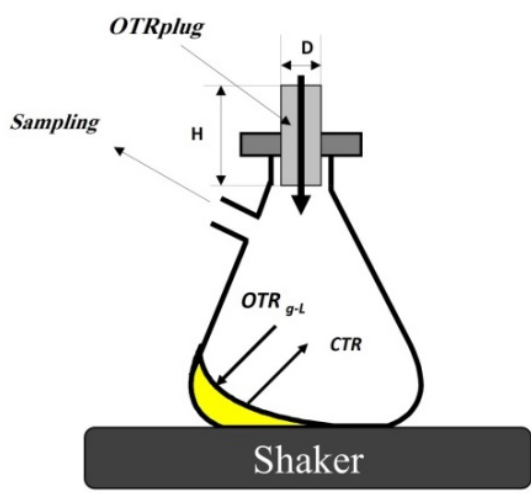

B

Figure 1. Miniaturized shaken bioreactor system. (A) Schematic drawing of gas transfer in an aerated flask (AF), (B) ventilation flask (VF) with sterile closures as offline technique which used in this research. 
Determining dry biomass, residual sugar, specific growth rate, specific GA production rate, and oxygen uptake

As mentioned earlier, an offline monitoring flask or ventilation flask was used to measure four parameters namely dry biomass, GA, residual sugar, and gene expression. The selected ventilation flasks have the same aeration value (1.2 vvm) as the aerated flask used in online monitoring. Mycelium was isolated from liquid media by centrifugation and was dried by a freeze dryer (Alpha 1-2 LD Plus, Christ, Germany) to measure dry cell weight. Residual sugar concentration was also measured by the phenol-sulfuric acid method [18]. The average specific growth rate $(\mu)$ and the specific $\mathrm{GA}$ production rate $\left(\mathrm{q}_{\mathrm{GA}}\right)$ were obtained from the following equations:

$$
\begin{array}{ll}
\mu=\frac{\operatorname{Ln}\left(\frac{\text { Final biomass }}{\text { Initial biomass }}\right)}{\text { fermentation time }} & \text { Equation } 4 \\
\mathrm{q}_{\mathrm{GA}}=\frac{1}{\mathrm{X}} \frac{d P}{\mathrm{dt}} & \text { Equation 5 }
\end{array}
$$

When $X$ is cell concentration. Oxygen consumption during cultivation was also determined by the integration of the OTR profile as follows:

$$
\text { Oxygen uptake }=\int_{0}^{t} \text { OTR. } d t
$$

Equation6

\section{Assay of Ganoderic Acid}

According to literature [18], GA was extracted after obtaining dried mycelium. Briefly, to extract GA, 100 $\mathrm{mg}$ of dried biomass is added to ethanol $50 \%(\mathrm{v} / \mathrm{v})$ twice for one week, and then biomass was isolated by centrifugation (25 $\mathrm{min}, 12,000 \mathrm{~g}$ ). Additionally, the supernatants were dried at $50^{\circ} \mathrm{C}$ under vacuum conditions, and the residue was dissolved in a few milliliters of water besides extracting the aqueous solution with $2 \mathrm{~mL}$ of chloroform. The GA extraction from chloroform is performed with $5 \% \mathrm{NaHCO}_{3}(\mathrm{w} / \mathrm{v})$ and the $\mathrm{pH}$ of the solution is adjusted by the addition of hydrochloric acid (below 3). GA residues were then extracted by chloroform and in the next step, the remaining chloroform was evaporated at $40^{\circ} \mathrm{C}$. The GA content was dissolved in absolute ethanol and measured at $245 \mathrm{~nm}$ in a spectrophotometer (T80, PG Instruments Limited, London) as standard [22].

\section{RNA Isolation and Quantitative real-time PCR}

A 0.1g Aliquot of mycelium was separated from the culture medium and frozen by liquid nitrogen. Total RNA was extracted by RNX plus (Sinacolon, Iran). cDNA synthesis was performed by a synthesizing kit (Amplicon, Denmark). The random primer was used for cDNA synthesis. Then, transcript levels of $h m g r$ and sqs were determined by quantitative real-time PCR using SYBR Green (Applied biosystem, USA). The $2^{-\Delta \Delta}$
CT method was employed to analyze relative gene expression [23]. 18srRNA primer was used as an internal control and to normalize the data for the gene expression. The sequences of the hmgr and sqs primers have been described in the literature. The primers sequences were as follows: $h m g r$ forward: 5 'GTCATCCTCCTATGCCAAAC-3', hmgr reverse: 5'GGGCGTAGTCGTAGTCCTTC-3', sqs forward: 5'ACAGTTGTCAGCGAAGAGC-3', sqs reverse: 5'CGTAGTGGCAGTAGAGGTTG-3', 18S rRNA forward: 5'TATCGAGTTCTGACTGGGTTGT-3', $18 \mathrm{~S}$ rRNA reverse: 5'-ATCCGTTGCTGAAAGTTGTAT-3' [24, 10].

The expression level 1 was selected for samples for the PDB culture and fold changes were done in comparison with it. An initial denaturation stage were at $95^{\circ} \mathrm{C}$ for $5 \mathrm{~min}$, the amplification conditions were in a three-step procedure: $30 \mathrm{~s}$ at $94^{\circ} \mathrm{C}$ (denaturation), 30 $\mathrm{s}$ at $56^{\circ} \mathrm{C}$ (annealing), and $30 \mathrm{~s}$ at $72^{\circ} \mathrm{C}$ (extension) followed by 40 cycles.

\section{Statistical analysis}

Experimental results were analyzed statistically using Student's t-test (S). All runs were carried out in triplicate. A probability $(p)$ value of less than 0.05 $(P<0.05)$ was taken as the level of significance.

\section{Results}

\section{Online monitoring}

Miniaturized shaken bioreactor system provides a rich source of data by studying the OTR profile in each fermentation period, such as physiological responses of aerobic microorganisms to specific culture conditions, inhibition of the product, diauxic growth, and other biological phenomena. The OTR evolutions of $\mathrm{AF}_{1}, \mathrm{AF}_{2}, \mathrm{AF}_{3}$, and $\mathrm{AF}_{4}$ during the cultivation of $G$. lucidum are shown in Figure 2. At first, in the first 100 $\mathrm{hr}$ of cultivation, no fundamental changes were detected. The OTR for $A F_{1}$ and $A F_{2}$ achieved their maximal values of 2 and $3.2 \mathrm{mmol} / \mathrm{Lh}$ at $150 \mathrm{hr}$ and $160 \mathrm{hr}$, respectively. Although by culturing under $A F_{1}$ and $A F_{2}$ the growth behavior of $G$. lucidum was the same, the maximal OTR of $A F_{2}$ was more than that of $A F_{1}$, which can be attributed to vitamin $B_{1}$. By analyzing the $\mathrm{AF}_{3}$ OTR profile, we found that two maximal values of 3.5 and $4.9 \mathrm{mmol} / \mathrm{Lh}$ occurred at $140 \mathrm{hr}$ and $210 \mathrm{hr}$, respectively. Furthermore, with fermentation in complex media $\left(\mathrm{AF}_{4}\right)$, maximal values of 3.8 and $10 \mathrm{mmol} /$ Lh occurred at $155 \mathrm{hr}$ and $220 \mathrm{hr}$, respectively.

The OTR evaluation results also indicated that with culturing in $A F_{1}$ and $A F_{2}$, the OTR curve sloped downward after achieving their maximum value. 


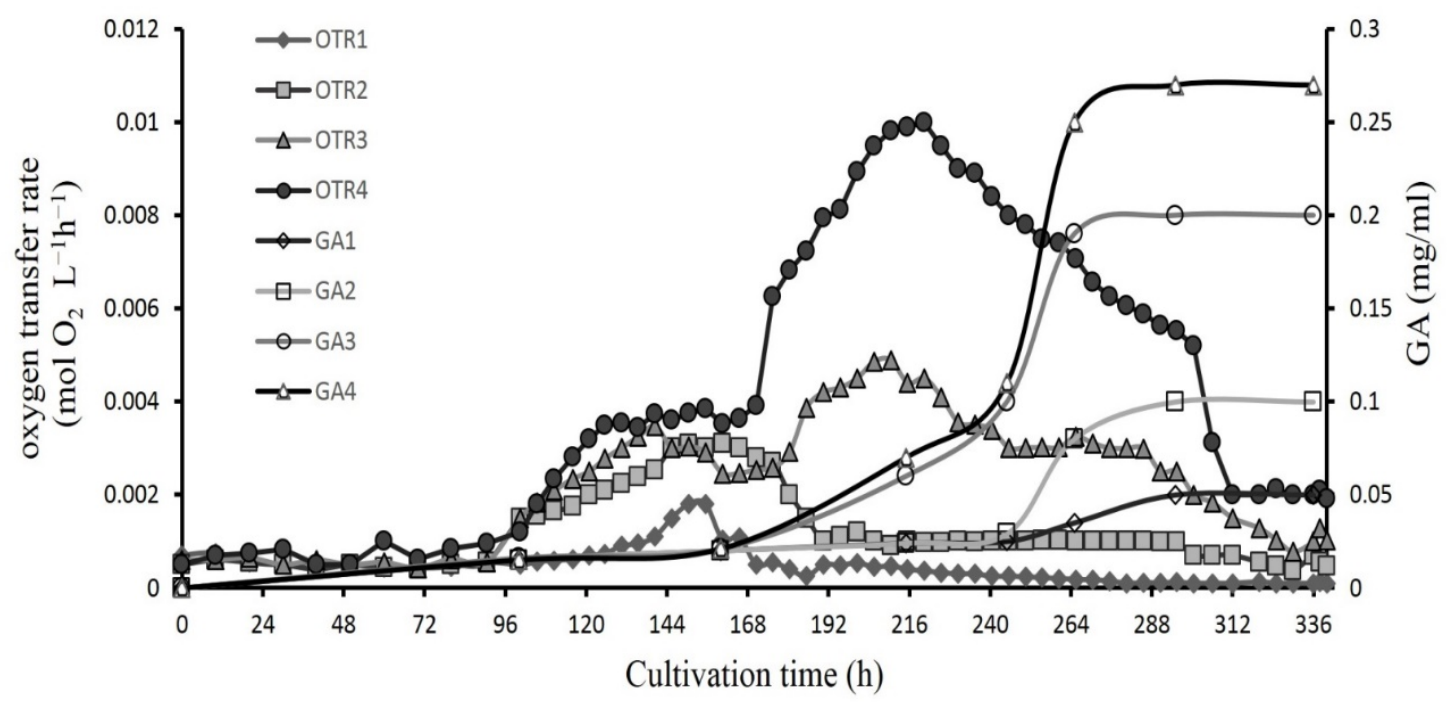

Figure 2. Evolution of oxygen transfer rate, expressed in mol/L'h using aerated shake flask (AF) and GA production expressed in $\mathrm{mg} / \mathrm{mL}$ using ventilation flask (VF) during culturing of $G$. lucidum with different media culture; $\mathrm{AF}_{1}$ and $\mathrm{VF}_{1}: \mathrm{PDB} \mathrm{AF}_{2}$ and $\mathrm{VF}_{2}$ : $P \mathrm{~PB}+$ vitamin $B_{1} ; A F_{3}$ and $V_{3}$ : YPG; $A_{4}$ and $V_{4}$ : complex medium $(n=3)$.

\section{Offline Monitoring}

Cultivation of $G$. lucidum using offline monitoring was also carried out to examine the biomass formation, GA biosynthesis, residual sugar, and gene expression during certain times. The combination of an offline and online monitoring can be beneficial for kinetic analysis of biomass formation and GA production.

Figure 3 shows the biomass production of $G$. lucidum during cultivation. After $48 \mathrm{hr}$, the biomass formation increased under $\mathrm{VF}_{1}-\mathrm{VF}_{4}$, and the maximum cell concentration was achieved after $192 \mathrm{hr}$. Then, the biomass almost remained constant until the end of the period despite the corresponding depletion of sugar concentration. During cultivation, a lag phase of two-day was considered for all the flasks. It is also observed that the culturing of $\mathrm{G}$. lucidum under $\mathrm{VF}_{4}$ yielded the maximum biomass (18.5 g DW/L) compared to other flasks. The maximum biomass accumulation under $\mathrm{VF}_{3}, \mathrm{VF}_{2}$, and $\mathrm{VF}_{1}$ were 15.25, 12.25 , and $11.25 \mathrm{~g} \mathrm{DW} / \mathrm{L}$, respectively. Evaluation of the total cell concentration during fermentation demonstrated that biomass production in a more complex broth culture $\left(\mathrm{VF}_{4}\right)$ was 1.6-times higher than that in the basal medium $\left(\mathrm{VF}_{1}\right)$. The sugar consumption profiles in all flasks have the same permanent declining trend. Further analysis shows that on the thirteenth day, residual sugar was almost depleted for all cases. Moreover, more complex media (flasks 3-4) that contain richer carbon sources experienced higher cell growth than less complex ones (flasks 1-2).

GA production analysis demonstrated that GA was produced after $144 \mathrm{~h}$ in all flasks and then by the rest of culturing this substance was accumulated continuously (Figure 2). Maximum GA production of $\mathrm{VF}_{4}$ was obtained equal to $270 \mathrm{mg} / \mathrm{L} 4$ times more than the $\mathrm{VF}_{1}$.

Further analysis demonstrated that by culturing $G$. lucidum under different media (flasks 1-4), gene expression of $h m g r$ and sqs had been experienced a sharp increase after $96 \mathrm{hr}$ (Figure 4), which coincides with the starting of GA biosynthesis (Figure 2). For more complex media (flasks 3-4), another increase is observed after $192 \mathrm{hr}$. Also, gene expression of $\mathrm{hmgr}$ and sqs at the end of cultivation were 1.45- and 2times higher than their initial value at beginning of culturing, respectively. The final gene expression analysis under different culture media demonstrated this parameter was increased 1.25 and 1.81 times in $\mathrm{VF}_{3}$, and 1.2 and 1.6 times in $\mathrm{VF}_{2}$ for $h m g r$ and $s q s$, respectively. In all cases, the gene expression of sqs was higher than that of hmgr. 

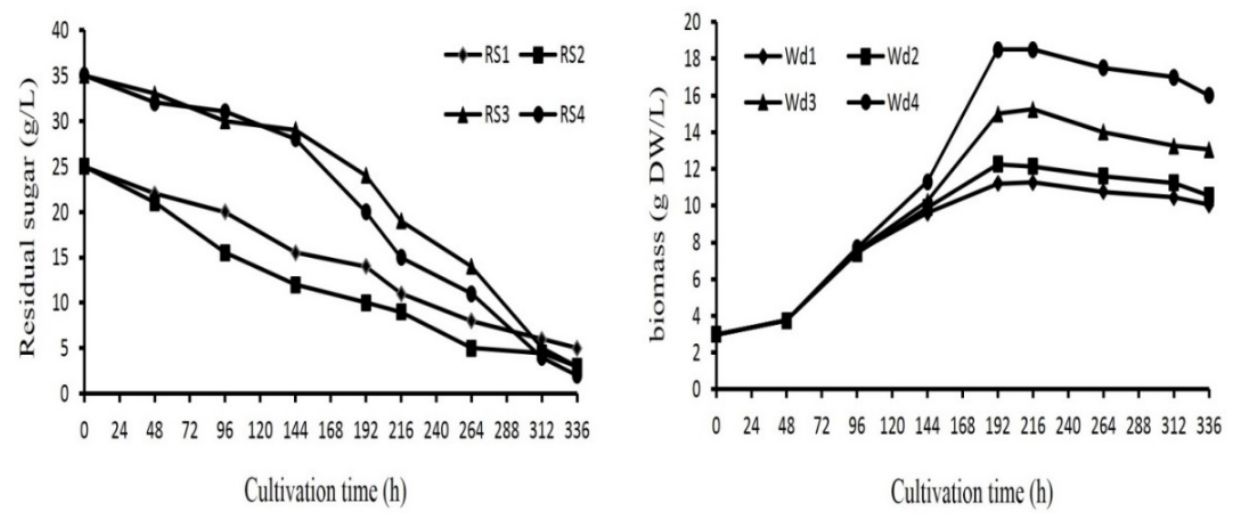

Figure 3. Monitoring of residual sugar and biomass formation expressed in $g / L$ and $g$ DW/L, respectively using ventilation flasks (VF) during culturing of $G$. lucidum with different media culture $(n=3)$.
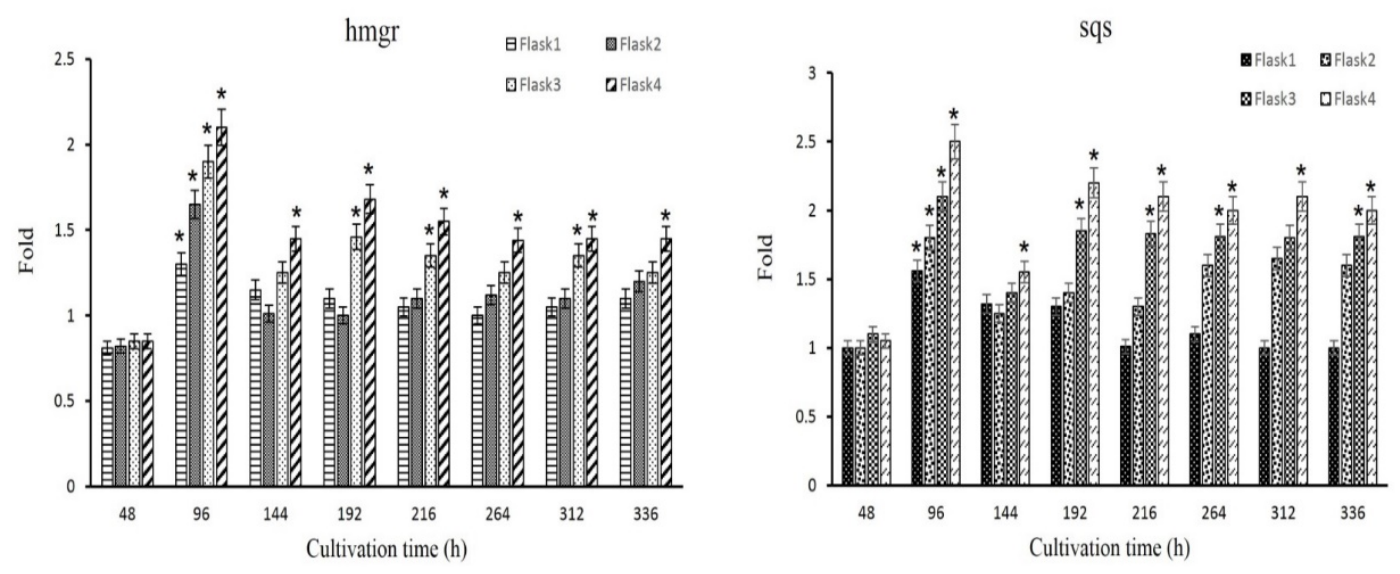

Figure 4. Comparison analysis of gene expression of $h m g r$ and sqs in flasks $1-4$ (*indicates $P<0.05$ compared to PDB culture).

\section{DISCUSSION}

\section{Kinetic Analysis of Biomass Formation and GA Production}

The kinetic profiles of the mycelial growth and the $\mathrm{GA}$ accumulation of $\mathrm{G}$. lucidum in the miniaturized shaken bioreactor systems in addition to residual sugar and gene expression were monitored and shown in four different media simultaneously.

According to the OTR profile of AFs through fermentation, the oxygen consumption for $A F_{4}, A F_{3}$, $A F_{2}$, and $A F_{1}$ were calculated to equal with $1.47,0.76$, 0.40 , and $0.17 \mathrm{~mol} / \mathrm{L}$, respectively. It is concluded that the oxygen consumption of $\mathrm{AF}_{4}$ including more complex media is 8.6-fold higher than that of $A F_{1}$ as a basal broth culture. Residual sugar analysis suggested that reducing in OTR values can be attributed to the depletion of carbon sources from media cultivation.

Measuring the average specific growth rate $(\mu)$ indicated that the $\mu$ for $V F_{4}, V F_{3}, V F_{2}$, and $V F_{1}$, was $0.237,0.211,0.190$, and $0.175 \mathrm{~d}^{-1}$, respectively.
Culturing under $\mathrm{VF}_{4}$ was approximately 1.4-times higher in growth compared to $\mathrm{VF}_{1}$.

With culturing by a more complex carbon medium (flask 4 ), the specific cell growth rate $(\mu)$ achieved two maximal values of $0.276 \mathrm{~d}^{-1}$ and $0.247 \mathrm{~d}^{-1}$ at $6 \mathrm{~d}$ and 8 $\mathrm{d}$ respectively. Moreover, culturing by using more than one carbon source (flask 3 ) the specific cell growth rate $(\mu)$ of $V_{4}$ obtained two maximal values equal to $0.252 \mathrm{~d}^{-1}$ and $0.190 \mathrm{~d}^{-1}$ at the same time. However, with fermentation under $\mathrm{VF}_{2}$ and $\mathrm{VF}_{1}$ (basal medium), the specific cell growth rate $(\mu)$ achieved maximal value of $0.190 \mathrm{~d}^{-1}$ and $0.175 \mathrm{~d}^{-1}$ at $8 \mathrm{~d}$. At maximum GA production, the growth curve can be divided into two phases: growth and production. Each phase has a specific growth rate $(\mu)$.

Also, by cultivation under $\mathrm{VF}_{4}$, the maximal specific GA production rate $\left(\mathrm{q}_{\mathrm{GA}}\right)$ was obtained $1.84 \times 10^{-3}$ (g GA. g/DW.h), which was almost 2.8-times higher than $V_{1} \quad 0.65 \times 10^{-3} \quad$ (g GA. g/DW.h). Consequently, compared to $\mathrm{VF}_{2}$ and $\mathrm{VF}_{1}$, the growth rate of $\mathrm{VF}_{4}$ and 
$\mathrm{VF}_{3}$ sharply increased, and the main GA was produced between 144-216 $\mathrm{h}$.

Transcript levels of $h m g r$ and sqs indicated that the maximum gene expression is accessible when GA starts to produce and after that, they have a steady trend, until the end of fermentation. Furthermore, more gene expression levels of flasks 3-4 can be attributed to enhancing in GA production.
Table 2 presents the growth behavior of G. lucidum in flask 4 during fermentation. The critical time courses are highlighted. It seems that the interval between hours 134 and 312 when the changes of biomass and GA production coincided with the OTR evolution, was the crucial time for G. Iudicum. Therefore, this interval is suggested as the critical time for G. lucidum growth.

Table 2. Growth behavior of $G$. lucidum under $\mathrm{AF}_{4}$ and $\mathrm{VF}_{4}$

\begin{tabular}{|c|c|c|c|c|c|c|c|}
\hline \multicolumn{2}{|c|}{$\begin{array}{l}\text { Time range }(\mathbf{h}) \\
\text { Monitoring }\end{array}$} & $0-96$ & $96-134$ & $134-168$ & $168-216$ & $216-312$ & $312-336$ \\
\hline \multirow[t]{2}{*}{$\begin{array}{c}\text { AF } \\
\text { (online) }\end{array}$} & \multirow[t]{2}{*}{$\begin{array}{c}\text { OTR } \\
\text { (mmol/Lh) }\end{array}$} & 0 & $\begin{array}{l}\text { increase } \\
\text { up to } 3.5\end{array}$ & $\begin{array}{c}\text { constant } \\
3.5\end{array}$ & $\begin{array}{l}\text { increase up } \\
\text { to } 10 \\
\text { OTR max: } 10\end{array}$ & $\begin{array}{c}\text { decrease to } \\
2\end{array}$ & $\begin{array}{c}\text { constant } \\
2\end{array}$ \\
\hline & & $\rightarrow$ & $\uparrow$ & $\rightarrow$ & $\uparrow$ & $\downarrow$ & $\rightarrow$ \\
\hline \multirow{6}{*}{$\begin{array}{c}\text { VF } \\
\text { (offline) }\end{array}$} & \multirow{2}{*}{$\begin{array}{l}\text { biomass } \\
\text { (g DW/L) }\end{array}$} & \multicolumn{2}{|c|}{$\begin{array}{c}\text { increase up to } 11.3 \\
\mu_{1}: 0.276\left(\mathrm{~d}^{-1}\right)\end{array}$} & \multicolumn{2}{|c|}{$\begin{array}{l}\text { increase up to } \\
\mu_{2}: 0.247\left(d^{-1}\right)\end{array}$} & \multicolumn{2}{|c|}{ almost constant } \\
\hline & & \multicolumn{2}{|c|}{$\uparrow$} & \multicolumn{2}{|r|}{$\uparrow$} & \multicolumn{2}{|c|}{$\rightarrow$} \\
\hline & \multirow{2}{*}{$\begin{array}{c}\text { GA } \\
(\mathrm{mg} / \mathrm{L})\end{array}$} & almost & roduction & \multicolumn{3}{|c|}{ increase up to 270} & constant \\
\hline & & \multicolumn{2}{|c|}{---} & \multicolumn{3}{|c|}{$\uparrow$} & $\rightarrow$ \\
\hline & \multirow{2}{*}{$\begin{array}{l}\text { Residual } \\
\text { sugar } \\
\text { (g/L) }\end{array}$} & almos & dy depletion & \multicolumn{3}{|c|}{ main sugar consumed } & $\begin{array}{c}\text { almost } \\
\text { exhausted }\end{array}$ \\
\hline & & \multicolumn{2}{|c|}{$\rightarrow$} & \multicolumn{3}{|c|}{$\downarrow$} & $\downarrow$ \\
\hline
\end{tabular}

The Yield of Oxygen Consumption per GA Production, Biomass Formation, and Productivity

As shown in Figures 2 and 3 , the ratio of biomass per GA production rose in 216 initial hours; however, it reached its lowest value afterward. Further, between hours 216 and 312 of fermentation, no cell growth is observed despite GA production. It can be argued that in this interval the GA production is partially growthassociated. To obtain more information about this interval, we measured the yield of oxygen consumption per GA biosynthesis ( $\left.\mathrm{Y}_{\mathrm{O} 2 / \mathrm{GA}}\right)$, the yield of oxygen consumption per biomass production $\left(\mathrm{Y}_{\mathrm{O} 2 / \mathrm{X}}\right)$, and the productivity $\left(\mathrm{Y}_{\mathrm{X} / \mathrm{GA}}\right)$ (Eq. 7, 8, and 9).

$$
Y_{\frac{O 2}{G A}} \quad\left(\mathrm{~mol} \cdot \mathrm{g}^{-1}\right)=\frac{\text { Oxygen consumption }\left(\mathrm{mol}^{-1} \mathrm{~L}^{-1}\right)}{\mathrm{GA} \text { production }\left(\mathrm{mg} \cdot \mathrm{mL}^{-1}\right)}
$$

Equation 7

$$
Y_{\frac{O 2}{X}}\left(\mathrm{~mol} . \mathrm{gDW}^{-1}\right)=\frac{\text { Oxygen consumption }\left(\mathrm{mol} \cdot \mathrm{L}^{-1}\right)}{\text { biomass production }\left(\mathrm{gDW} \cdot \mathrm{L}^{-1}\right)}
$$
Equation 8

$$
Y_{\frac{X}{G A}} \quad\left(\mathrm{gDW} \cdot \mathrm{g}^{-1}\right)=\frac{\text { biomass production }\left(\mathrm{gDW} \cdot \mathrm{L}^{-1}\right)}{\mathrm{GA} \text { production }\left(\mathrm{mg} \cdot \mathrm{mL}^{-1}\right)}
$$

Equation 9 For this purpose, a more complex medium (i.e. flask number 4) was chosen due to its high cell growth and secondary metabolite production. Based on oxygen consumption, GA production, and biomass formation, desired parameters such as $\mathrm{Y}_{02 / \mathrm{GA}}, \mathrm{Y}_{\mathrm{O}} / \mathrm{X}$, and productivity during fermentation were measured at given times (Figure 5).

The maximum $\mathrm{Y}_{02 / \mathrm{x}}$ was obtained in $264 \mathrm{~h}$ while no increase in cell growth is observed at this time (Figure 3). So, it can be concluded that a large portion of oxygen has been consumed to produce GA. Also, the highest amount of oxygen per GA biosynthesis is seen at $144 \mathrm{~h}$ in which GA starts to produce (Figure 2). In fact, at the beginning of GA production, the majority of oxygen was consumed. At this time, culturing $G$. lucidum has the highest productivity. As a consequence, these results could approve OTR trends (Figure 2).

Since most GA was synthesized between hours 192 and 312 , this interval was further analyzed to obtain more useful information. Between these ranges, oxygen consumption was not specified, and, this value should be subtracted from the amount of oxygen consumption by biomass formation to determine a better estimation of oxygen uptake by GA production. Therefore, two intervals were chosen; interval one (0$144 \mathrm{~h}$ ) in which there was no GA biosynthesis, and interval two (192-312 h) with the main GA production. In the first interval, oxygen consumption was 
calculated to be $0.225 \mathrm{~mol} / \mathrm{L}$. This value for the next interval, when GA began to produce, was $0.986 \mathrm{~mol} / \mathrm{L}$. Based on biomass analysis (Figure 3), the main mycelia was produced in the first interval (0-144 hr). On the other hand, the cell growth rate decreased in the second interval, suggesting that by secondary metabolites (GA) consumed most of the oxygen. Therefore, to measure GA's oxygen consumption amount of oxygen consumed by mycelia in interval two. Finally, the actual oxygen consumption by GA production and $\mathrm{Y}_{\mathrm{O} / \mathrm{GA}}$ was calculated to be equal with $0.761 \mathrm{~mol} / \mathrm{L}$ and $3.81 \mathrm{~mol} / \mathrm{g}$, respectively. It can be concluded that after reaching maximal biomass accumulation, most of the oxygen has been consumed by secondary metabolite, and consequently GA production was partially growth-associated.

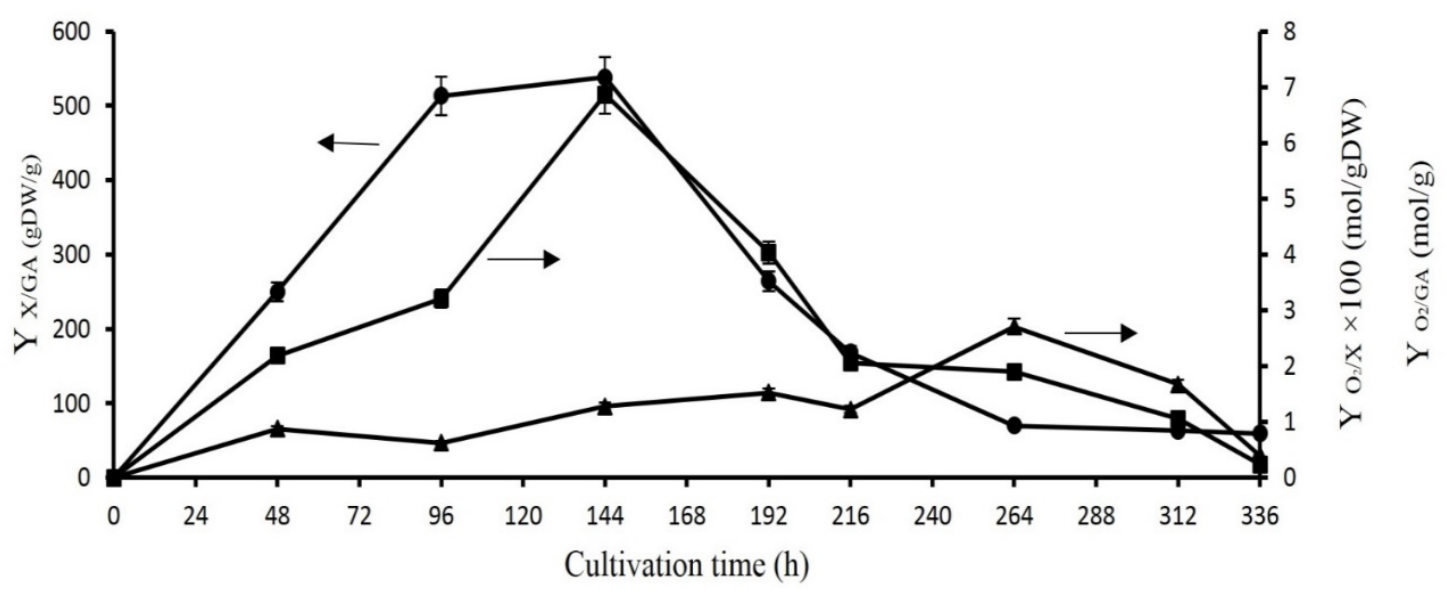

during the second interval, we should obtain the

Figure 5. Yield of oxygen consumption per GA production ( $\left.\mathrm{Y}_{\mathrm{O} 2 / \mathrm{GA}}\right)(\mathbf{\Xi})$, Yield of oxygen consumption per biomass production ( $\left.\mathrm{Y}_{\mathrm{O} 2 / \mathrm{X}}\right)$ $(\boldsymbol{\Delta})$, and productivity $\left(\mathrm{Y}_{\mathrm{X} / \mathrm{GA}}\right)(\bullet)$ of culturing $\mathrm{G}$. lucidum under more complex media (flask 4$)$. The error bars show the standard deviation $(n=3)$.

\section{Conclusion}

On-line and off-line $G$. lucidum cultivation monitoring provided insight into its growth kinetics during fermentation. Production of valuable metabolite, i.e, GA in various cultures media indicated that maximum oxygen consumption, cell concentration, and GA production occurred when this mushroom was cultured under a more complex medium (flask 4). High maximum biomass and GA production were obtained at an initial glucose concentration of $35 \mathrm{~g} / \mathrm{L}$ with the presence of vitamin and $\mathrm{KH}_{2} \mathrm{PO}_{4}$. Under these conditions, the growth curve was two-phase and oxygen limitation did not occur. A high cell respiratory activity, superior cell growth, and secondary metabolite production were observed under the cultivation of a more complex medium and as a result, this media can be suggested as an optimized media for G. lucidum. The start time of secondary metabolite production can also be estimated by using the OTR evaluation. It was indicated that GA production was partially growthassociated. Additionally, overexpression of $h m g r$ and sqs genes, which are involved in the GA's biosynthesis pathway, confirmed the results of monitoring. Earlier investigations have tried to examine different factors and conditions to enhance the production of $G$. lucidum. Despite prior research on G. lucidum, this study has introduced an online monitoring strategy that is more efficient, unsophisticated, and costeffective than conventional methods. Finally, since finding cell growth behavior during cultivation is always considered a challenging issue, this method can be beneficial for studying the growth kinetics of other mushrooms.

\section{Acknowledgment}

The authors would like to thank the Faculty of New Science and Technologies, University of Tehran. The authors also are so grateful to Mr. Ebrahim Amoabediny for his kindly efforts.

\section{Conflict of Interest}

The authors declared no conflicts of interest 


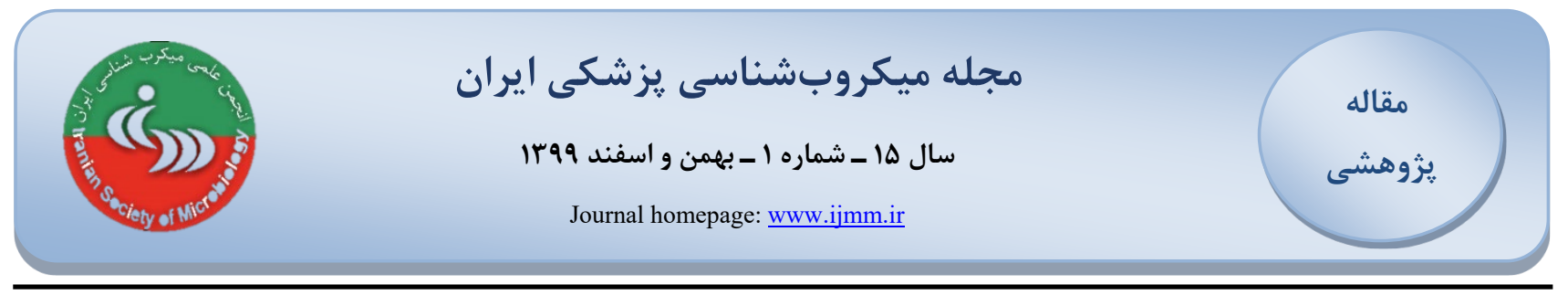

\title{
سينتيك رشد و توليد كنودريك اسيد ازكنودرما لوسيلوم GIRAN17

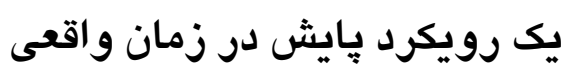

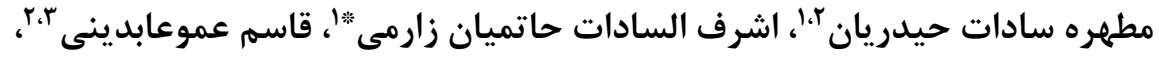

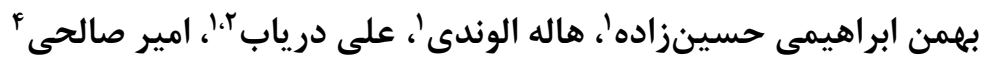

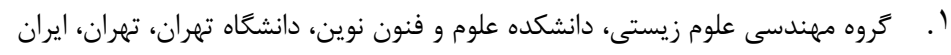

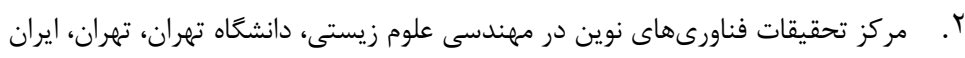

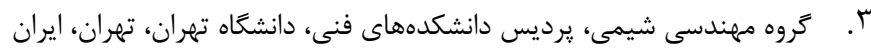

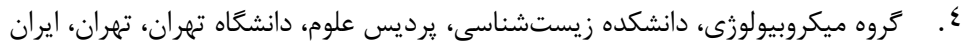

\begin{tabular}{|c|c|}
\hline جكيده & اطلاعات مقاله \\
\hline 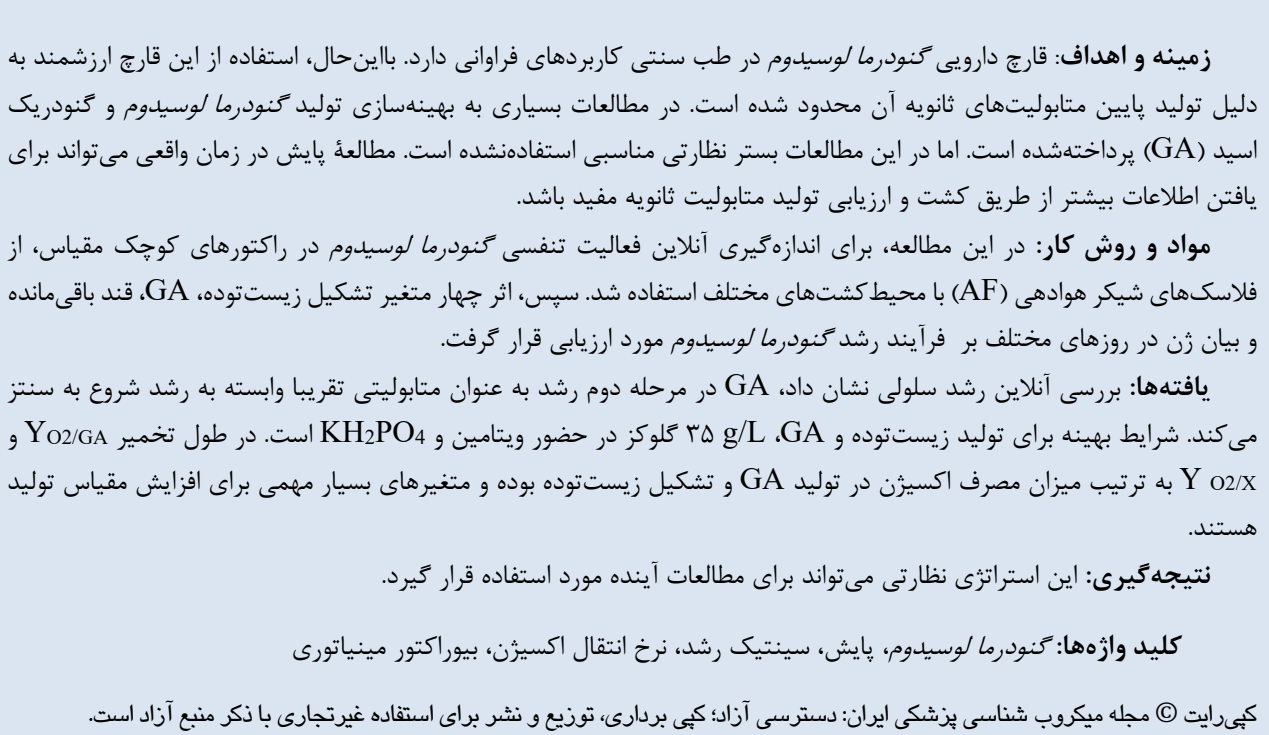 & 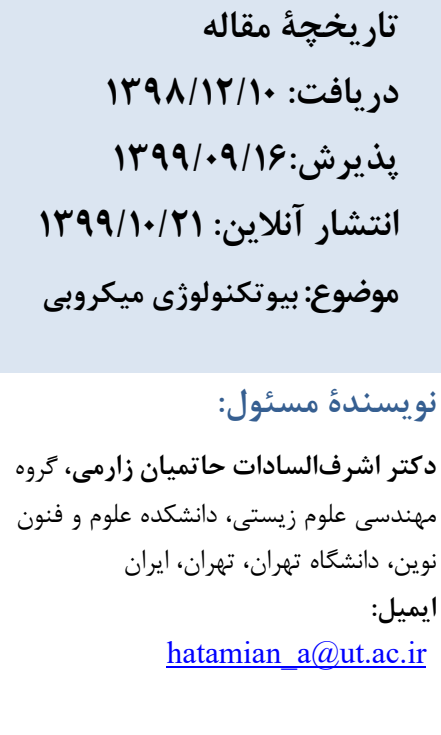 \\
\hline
\end{tabular}

مقدمه

باينحال، به دليل توليد يايين كنودريك اسيد از كنودرما لوسيدوم، استفاده از اين متابوليت ارزشمند محدود شده است.

از اين رو، در مطالعات بسيارى اثر متغيرهاى مختلف، از

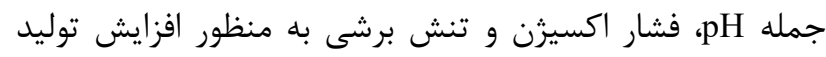

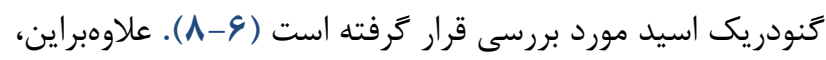

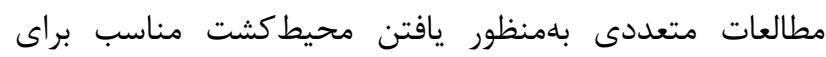

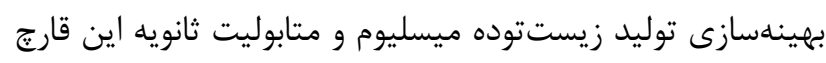
انجام شده است. اكرجه تحقيقات نشان مىدهد محيط غنىتر در
قارج َنودرما لوسيدوم بلطور گستردهاى در آسيا براى درمان

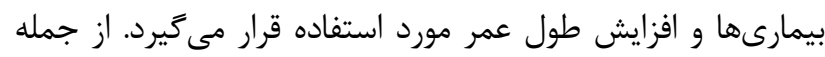

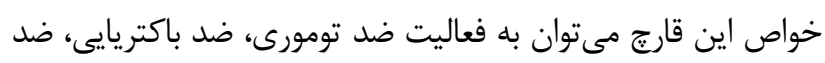

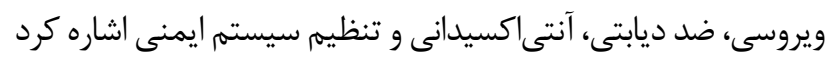

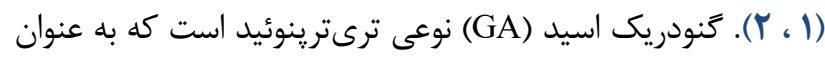

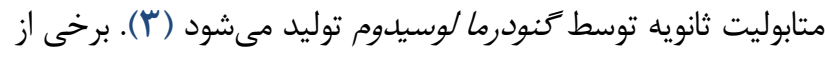

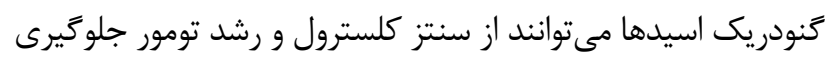

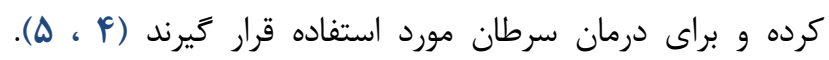


Carpinus betulus L. (Corylaceae) شده است (f)، (1). سويه كنودرما لوسيدوم بر اساس مطالعات بيشين در محيط يتيتو دكستروز آكار (PDA) كشت داده شد (1) (1).

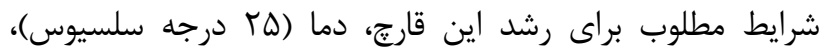

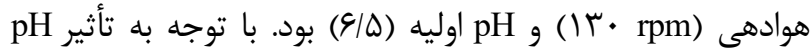
محيطكت بر توليد GA و رشد سلولى، pH محيط در دوره كشت ثابت نغلهداشته شد.

مطالعات نشان مىدهد غلظت بالاى كلوكز اوليه منجر به افزايش توليد زيستوده و بيوسنتز كنودريك اسيد مىشود (IV). همرجنين افزودن ويتامين B1 به محيط كشت سبب افزايش بهرهورى مىشود (11). فلاسكهاى شيكر هوادهى (آنلاين) و فلاسكهاى

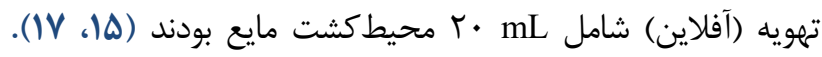

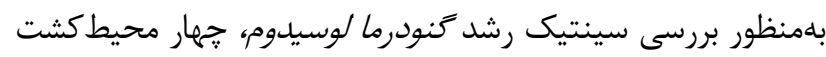

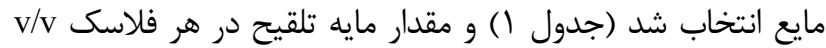

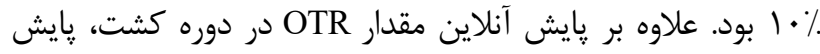

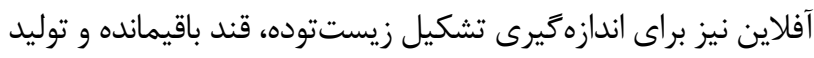

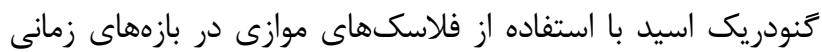

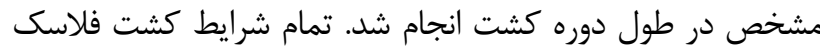
آنلاين و آفلاين براى هر كشت ثابت نعَه داشته شد.

\section{بيوراكتور شيكر كوجك مقياس}

براى اندازمكيرى آنلاين فعاليت هوازى كنودرما لوسيدوم در بيوراكتورهاى كوجى مقياس، از فلاسكهاى شيكر هوادهى (AF)

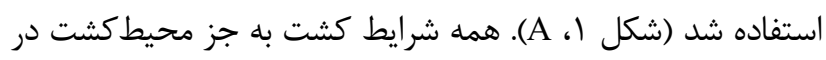

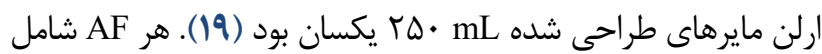
يك محيط كشت متفاوت بود: AF حاوى PDB و ويتامين B1، AF محيط كشت بيجيده بود (جدول (). بهطور خلاصه، بايش آنلاين بر اساس OTR انجام شد و فشارهاى جزئى با استفاده از يك سنسور اكسيزن كنترل شد. OTR با معادله زير محاسبه شد:

$$
O T R=\frac{\Delta \mathrm{p} O_{2}}{\Delta \mathrm{t}} \frac{V_{G}}{R T V_{L}} \quad \text { Equation } 1
$$

در اين معادله

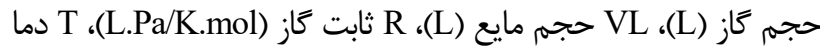

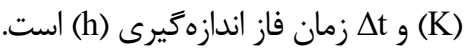

مقايسه با ساير محيطكشتها مانند محيط نيمه سنتتيك در رشد سلول و توليد متابوليتهاى ثانويه برتر هستند (9)، اما براى بهبود توليد، تحقيقات بيشترى لازم است.

همرجنين كزارش شده است با بهبود اكسيرنرسانى، بازده توليد

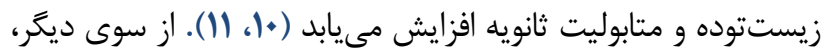
قبل از مطالعات افزايش مقياس، كشت سنتى نيازمند غربالكَى تعداد زيادى از نمونهها است؛ در نتيجه، بايد كشتهاى تكميلى بسيارى

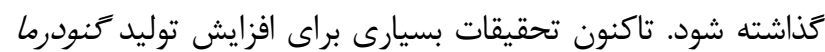
لوسيدوم انجام شده است؛ در همه اين مطالعات فقدان يك سيستم

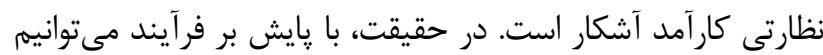

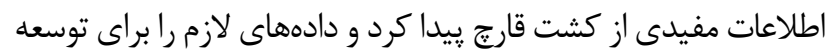

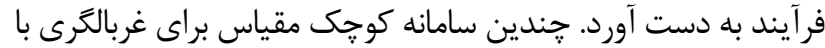
توان بالاو توسعه فرآيند ايجاد شده است. اما، يكى از كارآدمترين و ورين

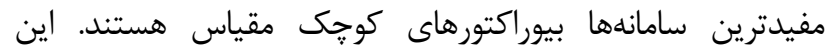
بيوراكتورها بهطور كستردهاى بهعنوان ابزارى براى غربالكَرى و كشف سيف مواد دارويى، بهينهسازى محيط كشت، سويه و توليد استفاده مىشوند بردي (ז). بيوراكتورهاى كوجى مقياس براى اندازهيرى نرخ انتقال

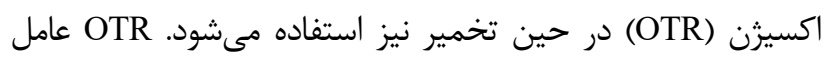
مهمى در به دست آوردن اطلاعات بيشتر از كشت سويهها است (س) (I). در مطالعه حاضر، براى اولين بار، بلطور همزمان يايش آنلاين و

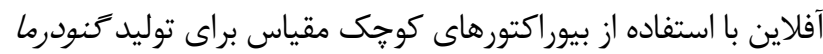

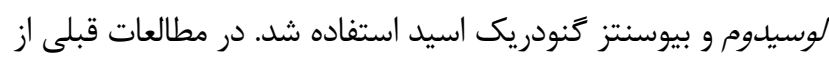
محيط كشتهاى مختلفى استفاده شده بود. بالين حال، در اين مطالعه، سعى شده است اثر متغيرهاى مختلف ارزيابى شود. در مطالعات يِيشين ما اثرات محيطكشت بر رشد قارج كنودرما لوسيدوم، ميزان مصرف اكسيزن و توليد كنودريك اسيد مورد بررسى درى قرار كرفت. بهنظر مىرسد رشد كنودرما لوسيدوم و توليد متابوليت

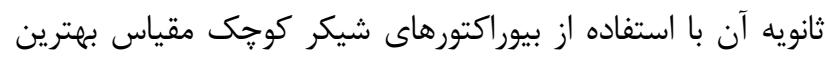
روش براى توليد حداكثر كنودريك اسيد باشد. اين دادهها بهمنظور يافتن راهى براى افزايش بازده كنودرما لوسيدوم بسيار سودمند است

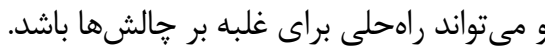

$$
\text { مواد و روشها }
$$

\section{سويه و شرايط كشت}

قارج كنودرما لوسيدوم (GIRAN17) از دانشكده علوم زيستى سنى دانشخاه شهيد بهشتى، تهران، ايران تهيه شد. اين قارج از درخت 


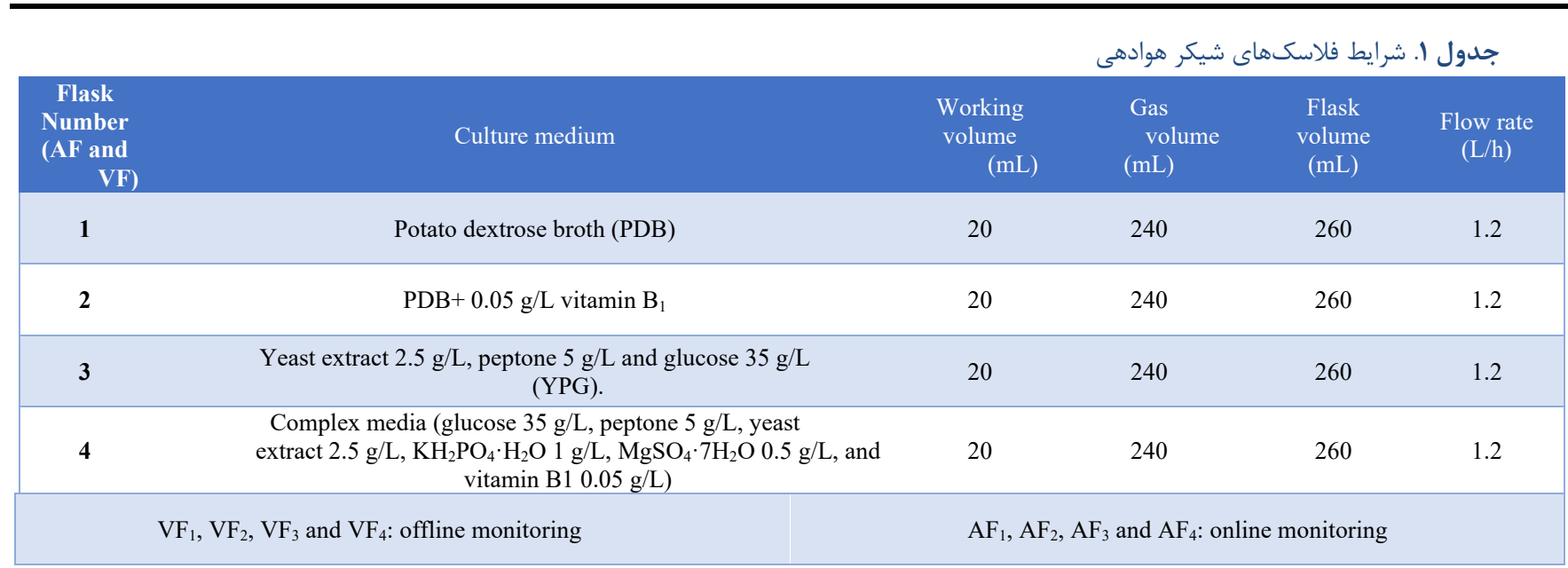

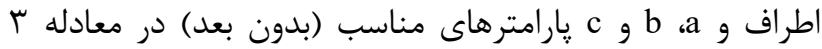

هستند.

$O T R_{\text {plug }}=k_{\text {plug }} \cdot\left(1 / V_{L} \cdot p_{\text {abs }}\right) \cdot\left(p O_{2, \text { out }}-p O_{2}\right)$

Equation 2

$k_{\text {plug }}=\frac{a \cdot O T R_{\text {plug }}}{b+O T R_{\text {plug }}+\frac{O T R_{\text {plug }}^{2}}{c}}$

Equation 3

for VF type $1 ; \mathrm{a}: 22.4 \times 10^{6}$, b: $6.95 \times 10^{3}$, c: 19.97 (Y)

بنابراين، براى يافتن اطلاعات بيشتر از رشد كنودرما

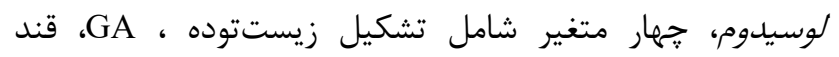

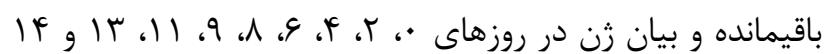
توسط ها سيستم VF بررسى شدند. هر آزمايش در دماى له درجه سلسيوس و rpm • سا به مدت جهارده روز نغلدارى شد.
فلاسكهاى HL • إرلن ماير، كه به آنها فلاسك تهويه كفته مىشود، نيز بهطور همزمان در شرايطى مشابه (VF)

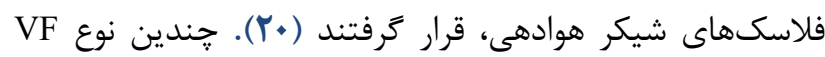
وجود دارد كه مقاومت جابجايى كاز در محفظه استريل آنها

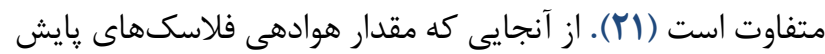

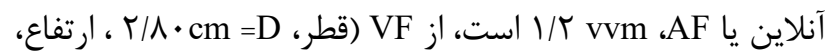
براى يايش آفلاين استفاده شد كه همان مقدار هوادهى AF را دارد (شكل I). معادلات ب و ب مربوط به ميزان انتقال اكسيرن ارتباط (OTR

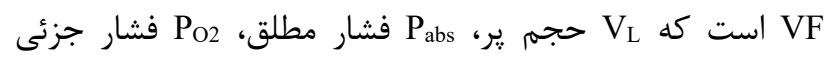
اكسيزن در فضاى فلاسك، PO2,out فشار جزئى اكسيزن در محيط فئ

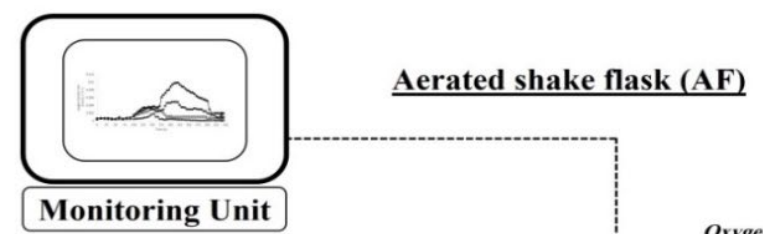

$\underline{\text { Ventilation flask (VF) }}$

Monitoring Unit

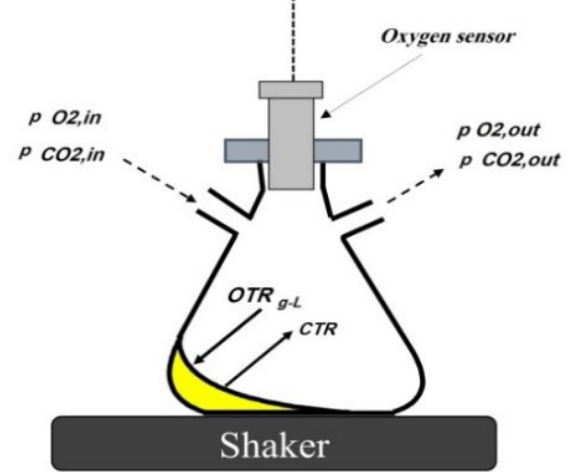

A

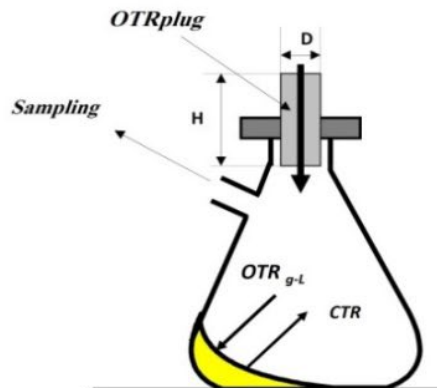

Shaker

B

شكل ا. سيستم بيوراكتور شيكر كوجك مقياس. (A) رسم شماتيك انتقال كاز در يك فلاسك شيكر هوادهى (AF)، (BF) فلاسك تهويه (V) با بسته شدن محفظه استريل به عنوان روش آفلاين در اين تحقيق استفاده شد. 
(سيناكولون، ايران). سنتز cDNA توسط يك كيت سنتزى (Amplicon)

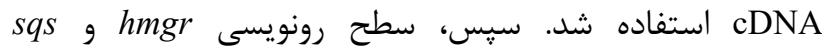

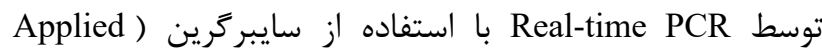

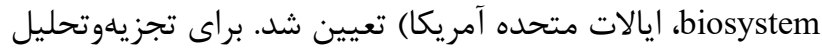
بيان نسبى زن از روش 18srRNA بهعنوان كنترل داخلى و نرمالسازى دادهنها براى بيان رادن استفاده شد. توالى آغازگرهاى hmgr و دو در مطالعات شرح داده شده است. توالىهاى آغازكرها به شرح زير بود: hmgr ،forward: 5'-GTCATCCTCCTATGCCAAAC-3' sqs ‘reverse: 5'-GGGCGTAGTCGTAGTCCTTC-3' sqs ‘forward: 5'-ACAGTTGTCAGCGAAGAGC-3' $18 \mathrm{~S}$ ،reverse: 5'-CGTAGTGGCAGTAGAGGTTG-3' ،RNA forward: 5'-TATCGAGTTCTGACTGGGTTGT-3' 18S rRNA reverse: 5'-ATCCGTTGCTGAAAGTTGTAT(1+ ، TY) 3'

سطح بيان ا براى نمونهها براى محيط كشت PDB انتخاب شد و تغييرات در مقايسه با آن بررسى شد. مرحله اول دناتوراسيون

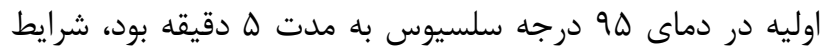

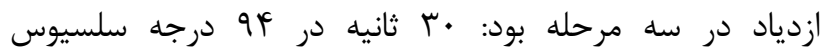

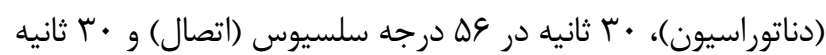

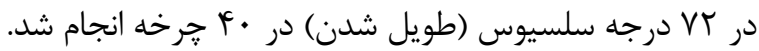

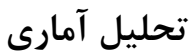

نتايج آزمايشها با استفاده از آزمون Student's t-test (S)

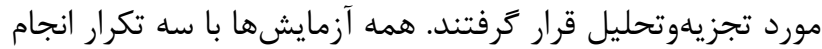

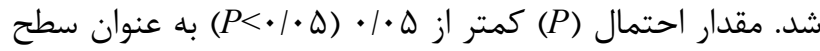
معنى دارى در نظر ترفته شد.

يافتهها

\section{بايش آنلاين}

بيوراكتور شيكر كوجك مقياس با مطالعه مشخصات OTR

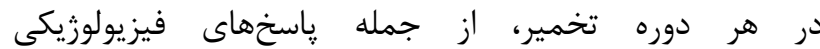
ميكروار كانيسمهاى هوازى به شرايط كشت خاص، مهار محصول، رشد دوفازى و ساير يديدههاى زيستى، منبع غنى از داده را فراهم مى كند. تغييرات OTR، در AF كنودرما لوسيدوم در شكل r نشان داده شده است. در . ․ ابتدايى كشت، هيج تغيير اساسى مشاهده نشد. OTR براى

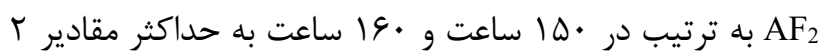

تعيين زيست توده، قند باقيمانده، نرخ ويزه رشد، ميزان

توليد GA و جذب اكسيزن

همانطور كه بيان شد، يك فلاسك پايش آفلاين يا فلاسك تهويه براى اندازمخيرى جهار متغير زيستتوده، GA، قند باقيمانده و بيان زن استفاده شدند. فلاسكهاى تهويه انتخاب شده همان مقدار هوادهى (1/T vvm) فلاسك هوادهى مورد استفاده در يايش آنلاين را دارند. ميسليوم قارج با استفاده از سانتريفيوز از

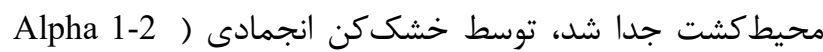

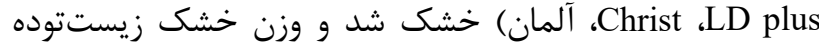
اندازهيرى شد. غلظت قند باقيمانده نيز با روش فنل-

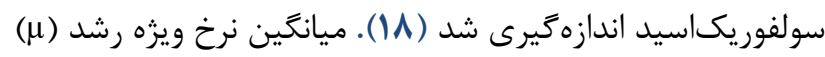
و ميزان توليد GA ويزه(qGA) از معادلات زير بهدست آمده است:

$\mu=\frac{\operatorname{Ln}\left(\frac{\text { Final biomass }}{\text { Initial biomass }}\right)}{\text { fermentation time }}$

Equation 4 $\mathrm{q}_{\mathrm{GA}}=\frac{1}{\mathrm{X}} \frac{\mathrm{dP}}{\mathrm{dt}}$

Equation 5

در اين معادله X غلظت سلول است. مصرف اكسيرن در دوره

كشت نيز با ادغام مشخصات OTR به شرح زير تعيين شد:

Oxygen uptake $=\int_{0}^{t} O T R \cdot d t$

Equation 6

\section{سنجش كَنودريك اسيد}

يس إز به دست آوردن ميسليوم خشك (1)، GA استخراج

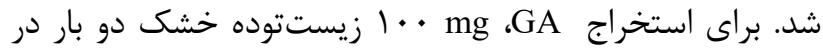

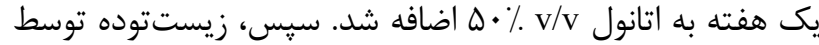

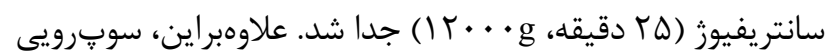
در شرايط خلا در دماى •D درجه سلسيوس خشك شد، بقاياى

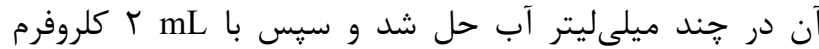

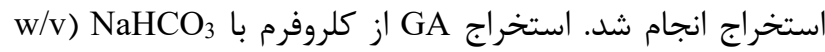

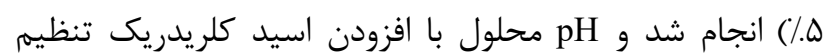
كرديد (زير ؟َ). يس از آن باقيمانده GA توسط كلروفرم استخراج

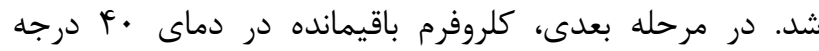

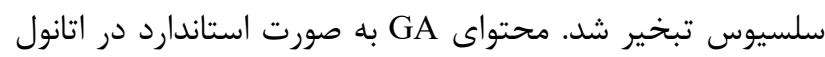
مطلق حل شد و در MFD nm توسط دستگاه اسيكتروفتومتر

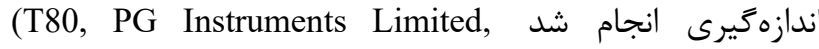

(Tr) London)

\section{Real-time PCR و RNA جداسازى}

مقدار g / • ميسليوم از محيط كشت جدا و توسط نيتروزن مايع منجمد شد. RNA كل توسط RNX plus استخراج شد مدرد 
علاوهبراين، با تخمير در محيطهاى ييجيده (AF4)، به ترتيب

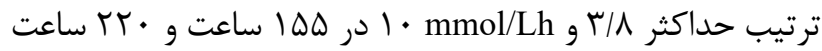
اتفاق افتاد. ارزيابى نتايج OTR همجهنين نشان داد كه با كشت در AF و AF $_{1}$ به سمت پايين شيب مىيابد.
و mmol/Lh رسيد. اگر جه با كشت در AFl/ و تنودرما لوسيدوم يكسان است، اما حداكثر OTR در AF2 بيشتر از AF تجزيهوتحليل مشخصات OTR در AF3، مشاهده شد دو مقدار

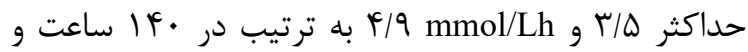
. إعاعت اتفاق افتاده است.

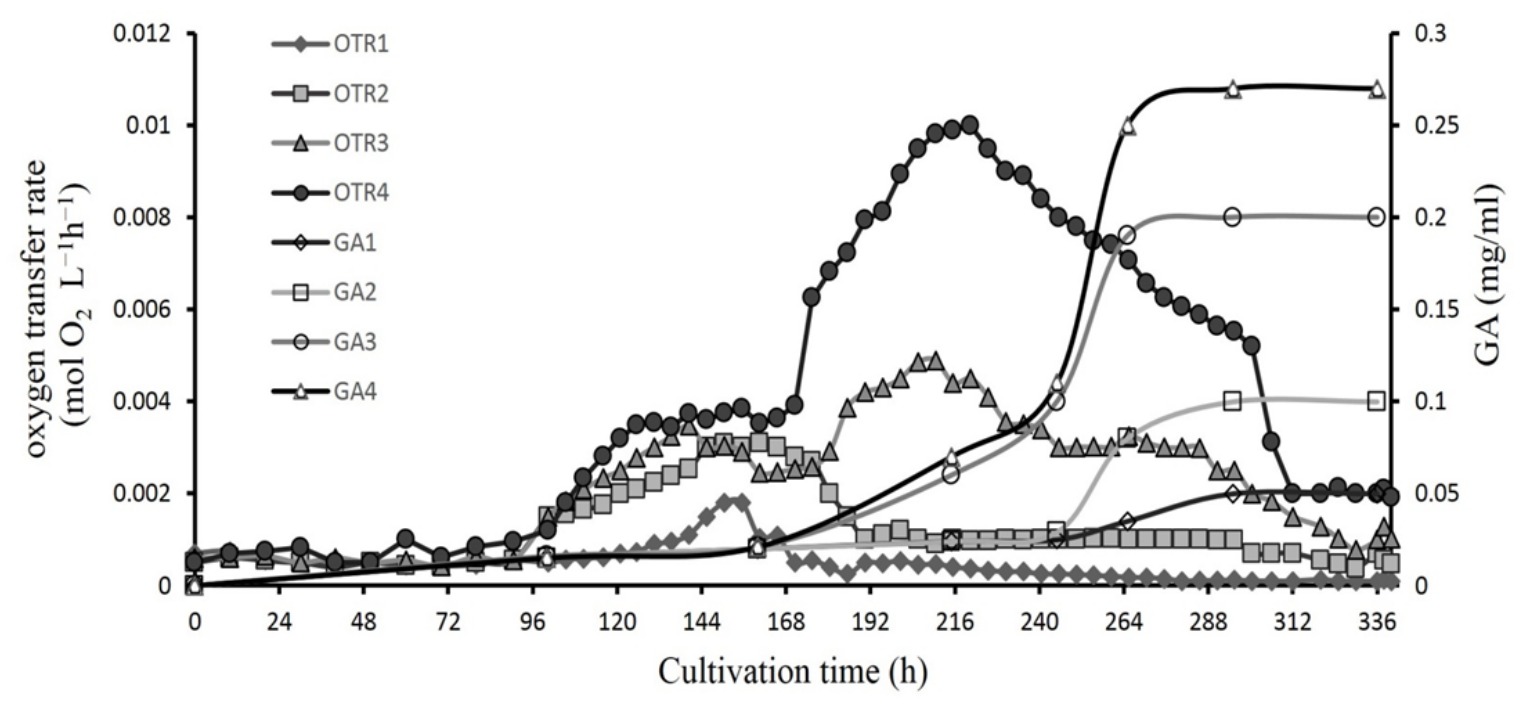

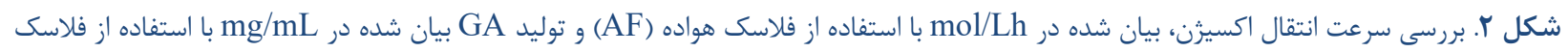
تهويه (VF) در طى كشت كنودرها لوسيدوم با محيط كشتهاى مختلف؛ .

يايش آفلاين

g به غلظت كل سلول در طى تخمير نشان داد توليد زيستتوده در

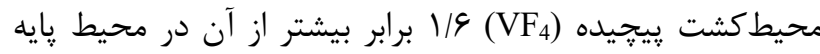
بود. يروفايلهاى مصرف شكر در همdٔ فلاسكها يك روند

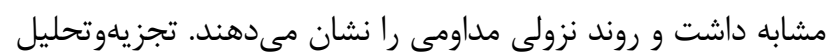
بيشتر نشان مىدهد در روز سيزدهم، قند باقيمانده تقريباً براى تمام

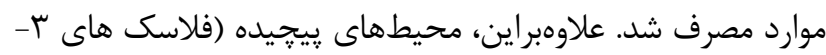
(F) كه حاوى منابع كربن غنىترى هستند، در مقايسه با محيطهاى

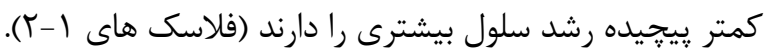

تجزيهوتحليل توليد GA نشان داد GA يس از \&AF أI ساعت در همه فلاسكها توليد مىشود و تجمع GA توسط مابقى كشت لوتيد ادامه مىيابد (شكل r). حداكثر توليد GA ، f برابر بيشتر از VF1 بهدست آمد.
كشت كنودرما لوسيدوم با استفاده از پايش آفلاين نيز براى

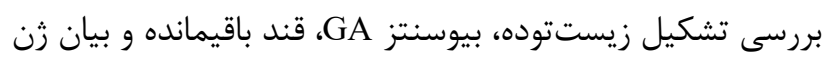
در زمانهاى مشخص انجام شد. تركيبى از يايش آفلاين و آنلاين مى تواند براى تجزيهوتحليل سينتيك تشكيل زيست رونوه و توليد GA شكل r توليد زيستتوده كنودرما لوسيدوم در طول دوره

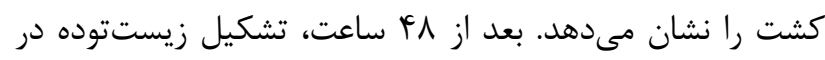

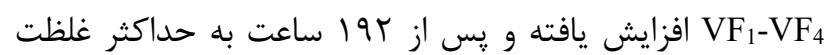

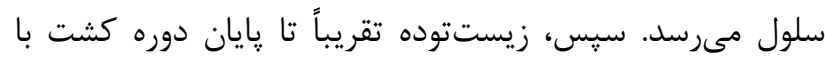

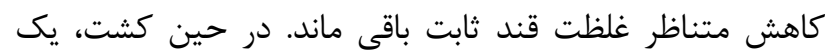
مرحله تاخير دو روزه براى همه فلاسكها در نظر كرفته شد.

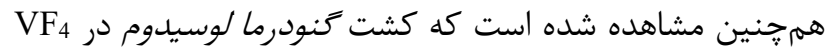
حداكثر زيست فلاسكها به همراه دارد. حداكثر تجمع زيستتوده در لVF 


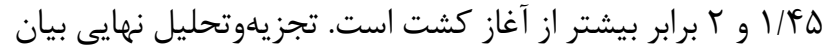
زن در محيطهاى مختلف كشت نشان داد بيان زن در

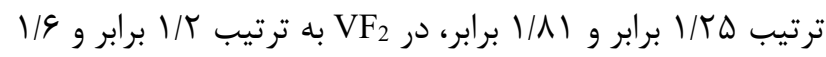

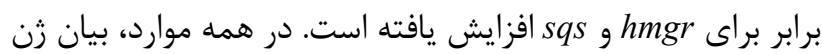
sqs
تجزيهوتحليل بيشتر نشان داد با كشت كنودرما لوسيدوم در

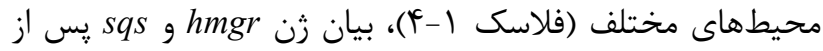

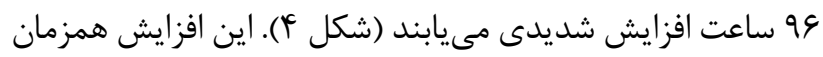
با شروع بيوسنتز GA است (شكل Y). در محيطهاى زيجيجيده

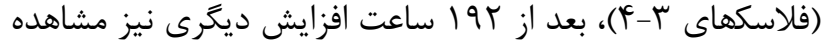

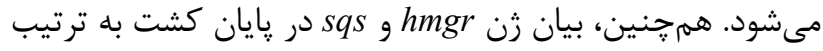
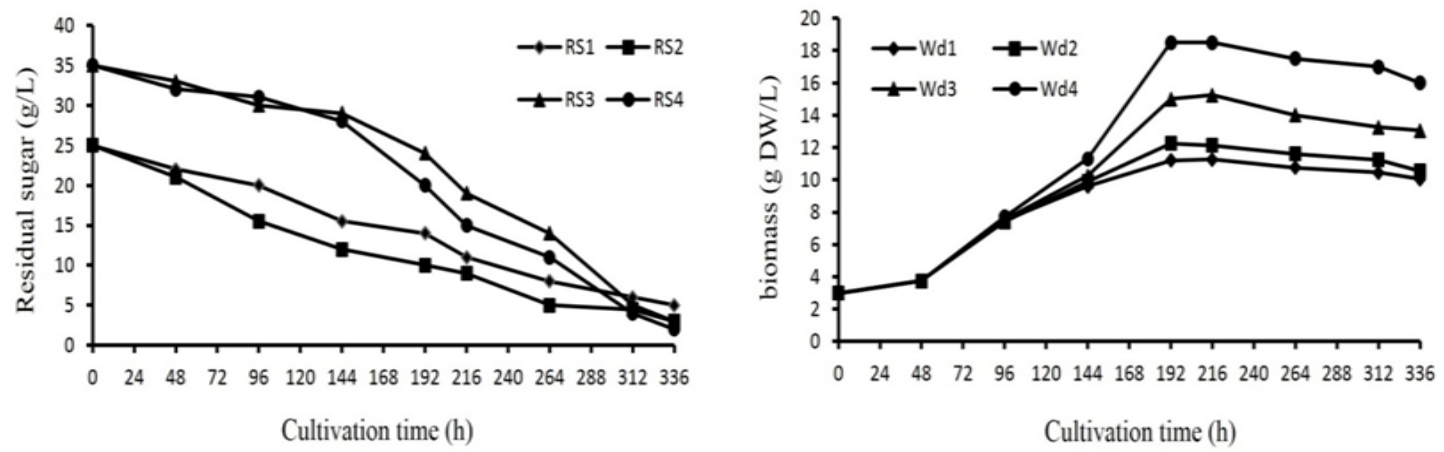

شكل r. پايش قند باقيمانده و تشكيل زيستتوده بيان شده در g/L g/L g g) به ترتيب با استفاده از فلاسك تهويه (VF) در طول كشت كنودرما لوسيدوم با محيط كشتهاى مختلف (r = n).
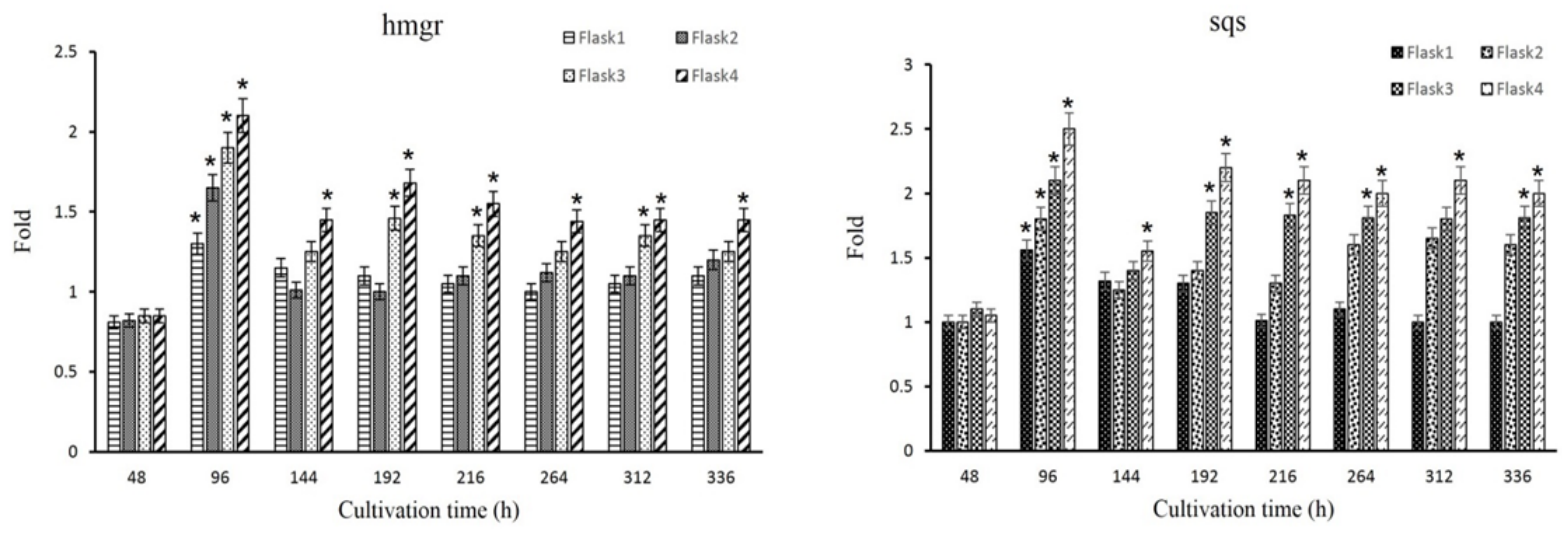

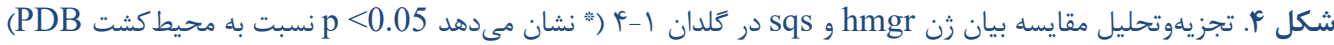

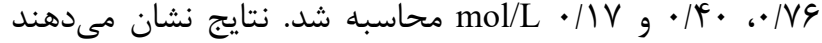
مصرف اكسيزن در AF4 كه محيطى ييجيدهتر بود N/9 برابر بيشتر از AF1 به عنوان يك محيط مشت يايه است. تجزيهوتحليل قند باقيمانده نشان داد كاهش مقادير OTR را مىتوان به كاهش منابع كربن در محيط كشت نسبت داد.

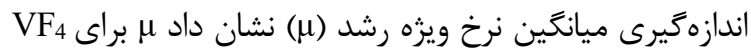
$\mathrm{d}^{-1}$ / IVD و ل $\mathrm{VF}_{1} \mathrm{VF}_{2}$ ، $\mathrm{VF}_{3}$ ، بود. رشد در كشت لدF4 مقر مقايسه با VF

\section{تجزيهوتحليل سينتيك تشكيل زيست توده و توليد} يروفايل سينتيك رشد ميسليوم گنودرما لوسيدوم و تجمع در بيوراكتور شيكر كوجك مقياس به همراه قند باقيمانده و بيان زن در تهار محيط كشت مختلف مورد بررسى قرار گرفت و بهوطور همزمان نشان داده شد.

با توجه به مشخصات OTR در OF Aها در طى تخمير، مصرف

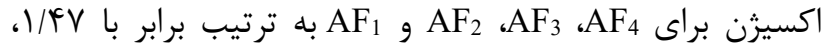


نتيجه، در مقايسه با VF2 و VF⿸

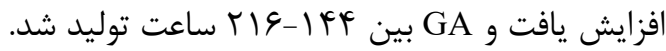

سطح رونويسى hmgr و sqs نشان داد، حداكثر بيان زن زمانى اتفاق مىافتد كه توليد GA شروع مىشود و سيس، توليد آن روند يايدارى تا پايان تخمير دارند. علاوهبراين، مىتوان سطح

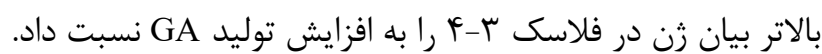

جدول r رفتار رشد كنودرما لوسيدوم در فلاسك أ در هنگام تخمير را نشان مى دهد. دورههاى زمانى حساس مشخص شدند. به

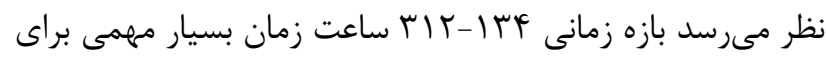
كنودرما لوسيدوم است كه همزمان با تغييرات مقدار زيست توده، توليد GA و OTR است. بنابراين، اين بازه به عنوان زمان اصلى رشد كنودرما لوسيلوم ييشنهاد مىشود.
با كشت در يك محيط كربنى پيجِيده (فلاسك f)، نرخ ويزه

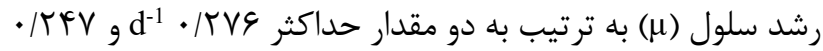

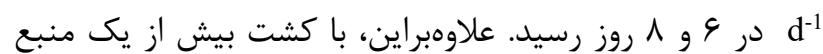

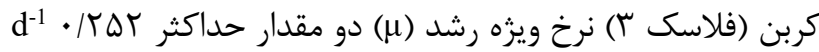

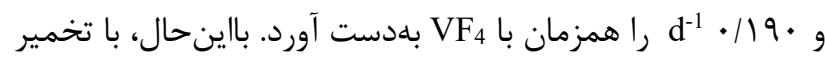
در VF2 و VF1

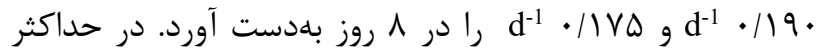
توليد GA، منحنى رشد را مىتوان به دو مرحله تقسيم كرد كه يكى به رشد و ديخرى به توليد اشاره دارد. هر فاز يك نرخ ويثه رشد (ر) دارد.

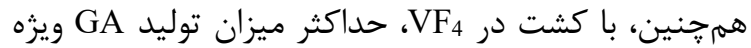

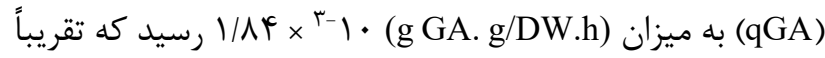

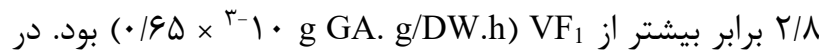

جدول r. رفتار رشد كنودرما لوسيدوم در AF4

\begin{tabular}{|c|c|c|c|c|c|c|c|}
\hline \multicolumn{2}{|c|}{$\begin{array}{l}\text { Time range (h) } \\
\text { Monitoring }\end{array}$} & $0-$ & $96-134$ & 134-168 & 168-216 & 216-312 & $312-336$ \\
\hline \multirow[t]{2}{*}{$\underset{\text { (online) }}{\mathrm{AF}}$} & \multirow[t]{2}{*}{$\begin{array}{c}\text { OTR } \\
(\mathbf{m m o l} / \mathrm{Lh})\end{array}$} & 0 & $\begin{array}{c}\text { increase up to } \\
3.5\end{array}$ & constant 3.5 & $\begin{array}{c}\text { increase up to } \\
10 \\
\text { OTR }_{\text {max }}: 10\end{array}$ & $\begin{array}{r}\text { decrease } \\
\text { to } 2\end{array}$ & $\begin{array}{l}\text { constant } \\
2\end{array}$ \\
\hline & & $\rightarrow$ & $\uparrow$ & $\rightarrow$ & $\uparrow$ & $\downarrow$ & $\rightarrow$ \\
\hline \multirow{6}{*}{$\begin{array}{c}\text { VF } \\
\text { (offline) }\end{array}$} & \multirow{2}{*}{$\begin{array}{c}\text { biomass } \\
\text { (g DW/L) }\end{array}$} & \multicolumn{2}{|c|}{$\begin{array}{c}\text { increase up to } 11.3 \\
\mu_{1}: 0.276\left(\mathrm{~d}^{-1}\right)\end{array}$} & \multicolumn{2}{|c|}{$\begin{array}{l}\text { increase up to } \\
\mu_{2}: 0.247\left(\mathrm{~d}^{-1}\right)\end{array}$} & \multicolumn{2}{|c|}{ almost constant } \\
\hline & & \multicolumn{2}{|r|}{$\uparrow$} & \multicolumn{2}{|c|}{$\uparrow$} & \multicolumn{2}{|c|}{$\rightarrow$} \\
\hline & \multirow{2}{*}{$\underset{(\mathrm{mg} / \mathrm{L})}{\mathbf{G A}}$} & & production & \multicolumn{3}{|c|}{ increase up to 270} & constant \\
\hline & & & -- & \multicolumn{3}{|c|}{$\uparrow$} & $\rightarrow$ \\
\hline & \multirow{2}{*}{$\begin{array}{c}\text { Residual sugar } \\
(\mathrm{g} / \mathrm{L})\end{array}$} & & steady depletion & \multicolumn{3}{|c|}{ main sugar consumed } & $\begin{array}{l}\text { almost } \\
\text { exhausted }\end{array}$ \\
\hline & & \multicolumn{2}{|r|}{$\rightarrow$} & \multicolumn{3}{|c|}{$\downarrow$} & $\downarrow$ \\
\hline
\end{tabular}

Equation 7

$Y_{\frac{O 2}{G A}}\left(\mathrm{~mol} \cdot \mathrm{g}^{-1}\right)=\frac{\text { Oxygen consumption }\left(\mathrm{mol}^{-\mathrm{L}^{-1}}\right)}{\text { GA production }\left(\mathrm{mg} \cdot \mathrm{mL}^{-1}\right)}$

Equation 8

$Y_{\frac{O 2}{X}}\left(\right.$ mol.gDW $\left.{ }^{-1}\right)=\frac{\text { Oxygen consumption }\left(\mathrm{mol}^{-\mathrm{L}^{-1}}\right)}{\text { biomass production }\left(\mathrm{gDW} \cdot \mathrm{L}^{-1}\right)}$

Equation 9

$Y_{\frac{X}{G A}}\left(\mathrm{gDW} \cdot \mathrm{g}^{-1}\right)=\frac{\text { biomass production }\left(\mathrm{gDW} \cdot \mathrm{L}^{-1}\right)}{\mathrm{GA} \text { production }\left(\mathrm{mg} \cdot \mathrm{mL}^{-1}\right)}$

بدين منظور، يك محيط ِيجِيدهتر (بهعنوان مثال فلاسك شماره ؟) به دليل رشد بالاى سلول و توليد متابوليت ثانويه، انتخاب شد. بر اساس مصرف اكسيزن، توليد GA و تشكيل

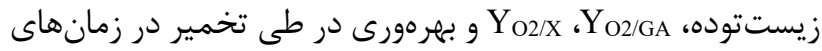
مشخص شده اندازهزيرى شد (شكل ه).
بازده اكسيثزن مصرفى به ازاى توليد GA، تشكيل

زيست توده و بهرهورى

همانطور كه در شكل r و r نشان داده شده است، نسبت زيستتوده به توليد GA در عاب ساعت ابتدايى افزايش يافته است. اما يس از آن به كمترين مقدار خود رسيد. بهعلاوه، بين

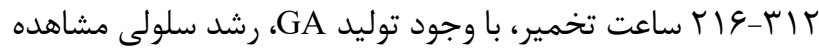
نمىشود. مىتوان ادعا كرد در اين فاصله توليد GA تا حدى به

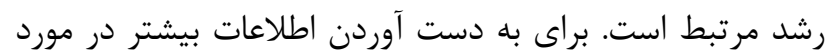

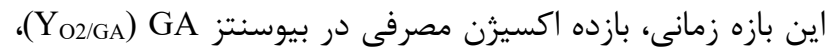
بازده اكسيرن مصرفى در توليد زيستتوده (Y)

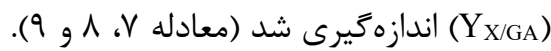




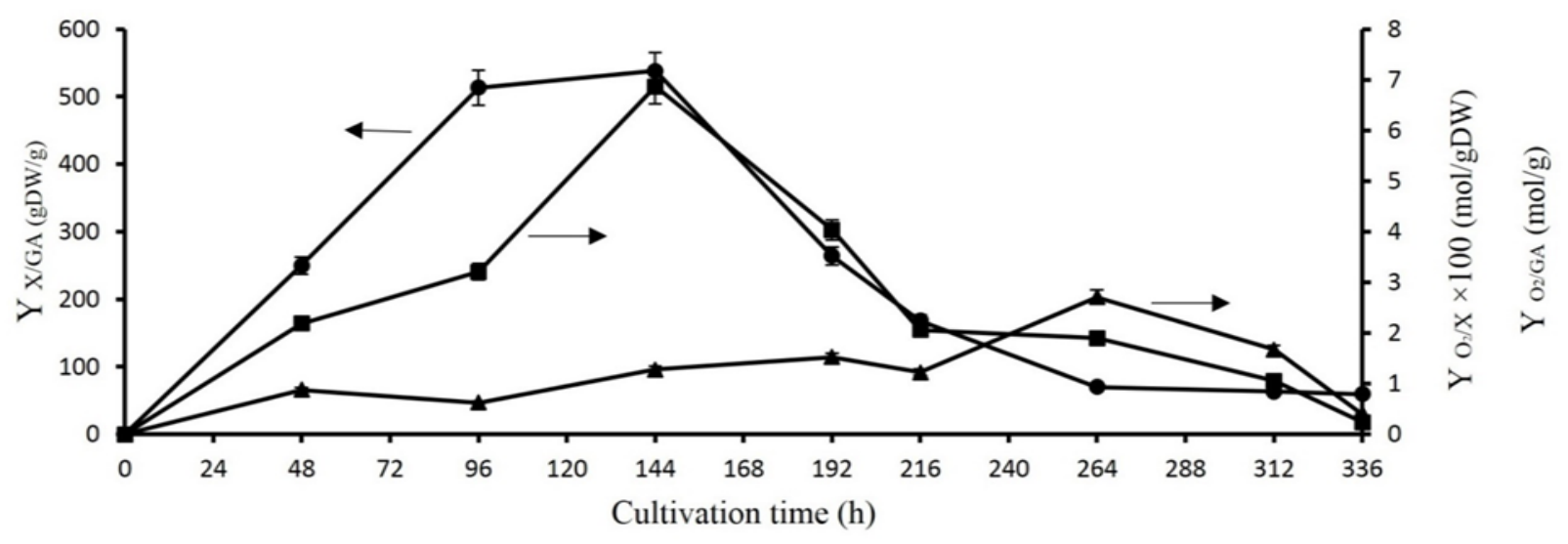

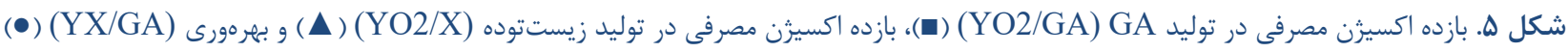

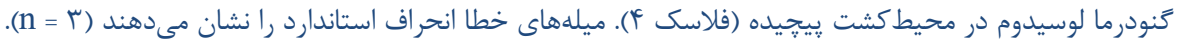

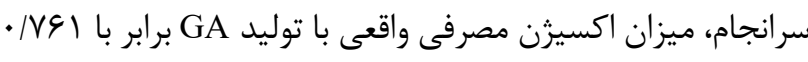

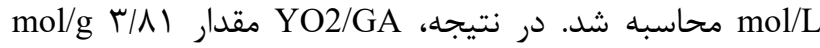

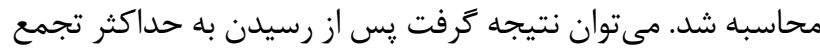

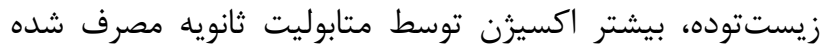

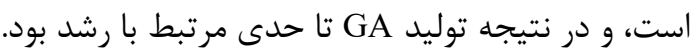

\section{نتيجهذيرى}

پايش آنلاين و آفلاين كشت كنودرما لوسيدوم بينشى از سينتيك رشد آن در طى تخمير فراهم كرده است. توليد متابوليت ارزشمند GA در محيط نشتهاى مختلف كشت نشان داد حرد دراكثر

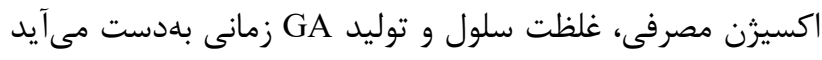

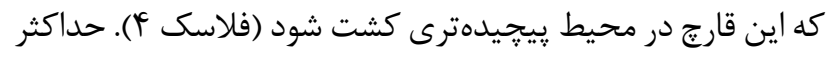
زيستتوده و توليد GA در غلظت اوليه كلوكز g/L هـآ، حضور ويتامين و زيتون

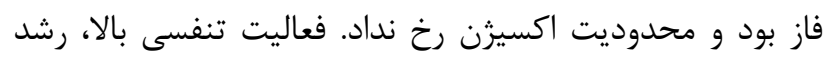

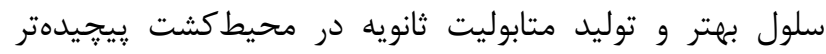

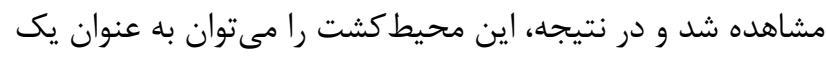

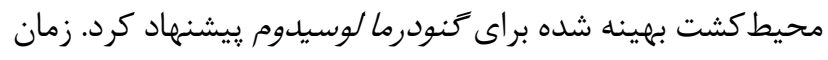

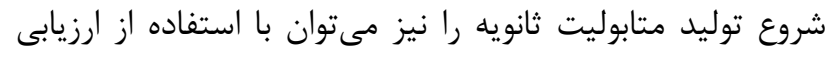

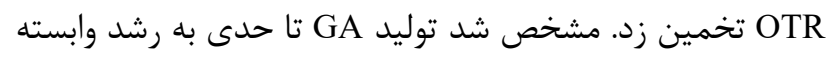

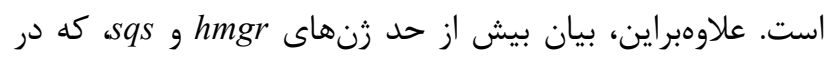

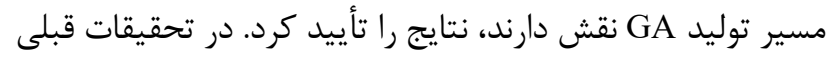

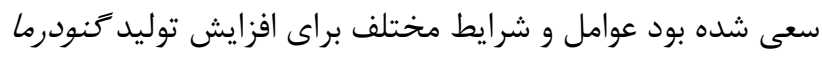

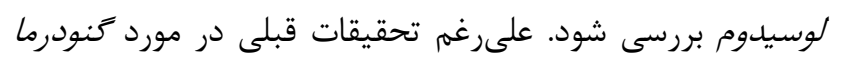

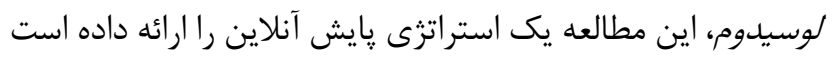

حداكثر Y2/X در Y Y T ساعت بهدست آمد در حالى كه در اين

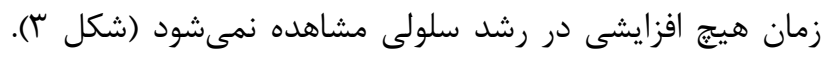

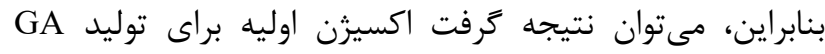

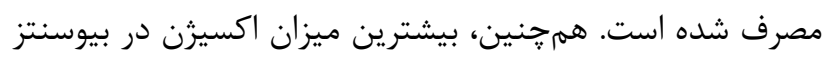

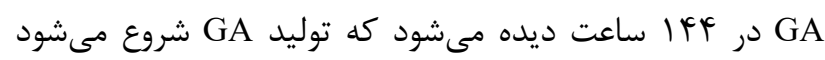

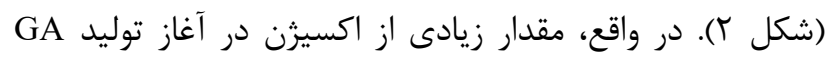

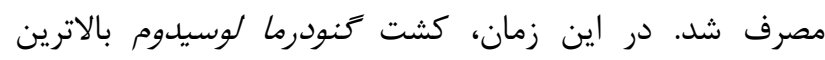

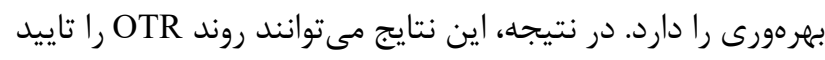

كنند (شكل r).

از آنجايى كه بيشتر GA بين 19 أنا rاس ساعت توليد شده

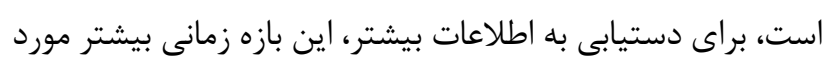

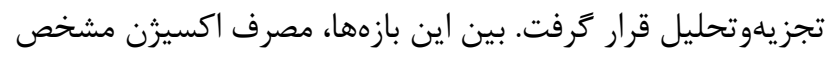

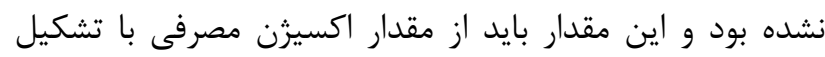

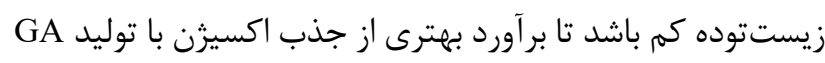

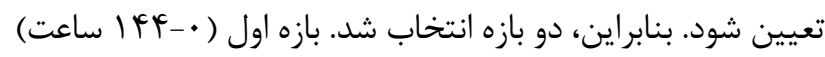

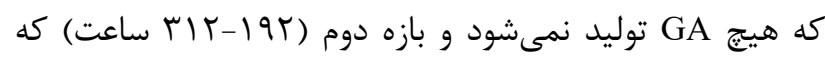

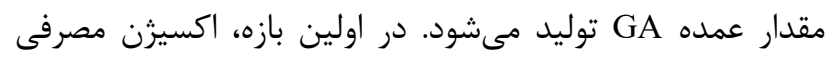

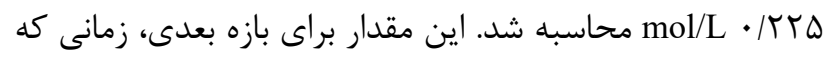
GA

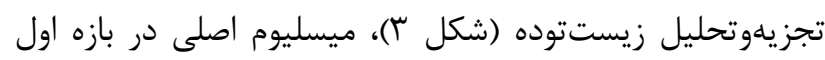

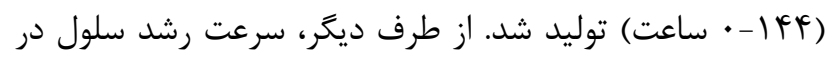

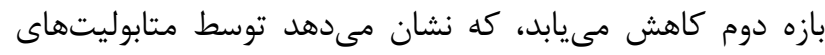

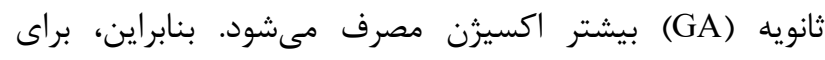

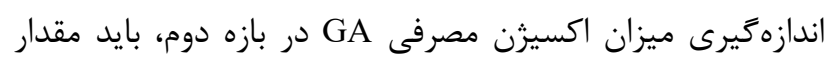

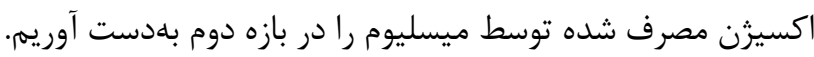




$$
\begin{aligned}
& \text { مى گردد. همرجنين از زحمات جناب آقاى ابراهيم عموعابدينى } \\
& \text { بسيار سياسگزارى مى گَردد. } \\
& \text { تعارض در منافع } \\
& \text { اين مقاله، يزوهشى مستقل است كه بدون حمايت مالى لى لماه } \\
& \text { سازمانى انجام شده است. در انجام مطالعه حاضر، نويسندگان } \\
& \text { هيج گونه تضاد منافعى نداشتهاند. }
\end{aligned}
$$

\section{Referance}

1. Kang Q, Chen S, Li S, Wang B, Liu X, Hao L, Lu J. Comparison on characterization and antioxidant activity of polysaccharides from Ganoderma lucidum by ultrasound and conventional extraction. International Journal of Biological Macromolecules., 2019; 124: 1137-1144. [DOI:10.1016/j.ijbiomac.2018.11.215] [PMID]

2. Sanodiya BS, Thakur GS, Baghel RK. Ganoderma lucidum: a potent pharmacological macrofungus, Curr Pharm Biotechnol., 2009; 10: 717-742. [DOI:10.2174/138920109789978757] [PMID]

3. Frisvad JC, Andersen B, Thrane U. The use of secondary metabolite profiling in chemotaxonomy of filamentous fungi, Mycol Res., 2008; 112:231-240. [DOI:10.1016/j.mycres.2007.08.018] [PMID]

4. Kalantari-Dehaghi S, Hatamian-Zarmi A, EbrahimiHosseinzadeh B, Mokhtari-Hosseini ZB, Nojoki F, Hamedi J, Hosseinkhani S. Effects of microbial volatile organic compounds on Ganoderma lucidum growth and ganoderic acids production in Co-vcultures (volatile co-cultures). Prep Biochem Biotechnol. 2019; 49(3):286-297. [DOI:10.1080/10826068.2018.1541809] [PMID]

5. Gao JJ, Min BS, Ahn EM. New triterpene aldehydes, lucialdehydes AC, from Ganoderma lucidum and their cytotoxicity against murine and human tumor cells, Chem Pharm Bull., 2002; 50:837-840. [DOI:10.1248/cpb.50.837] [PMID]

6. Wu GS, Lu JJ, Guo JJ. Ganoderic acid DM, a natural triterpenoid, induces DNA damage, G1 cell cycle arrest and apoptosis in human breast cancer cells, Fitoterapia., 2012; 83: 408-414. [DOI:10.1016/j.fitote.2011.12.004] [PMID]

7. Fang, QH, Zhong JJ. Effect of initial $\mathrm{pH}$ on production of ganoderic acid and polysaccharide by submerged fermentation of Ganoderma lucidum, Process Biochem., 2002; 37:769-774. [DOI:10.1016/S0032-9592(01)00278-3]

$$
\begin{aligned}
& \text { كه كارآمدتر، يِيجيدهتر و مقرون به صرفهتر از روشهاى معمول }
\end{aligned}
$$

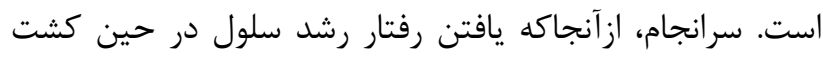

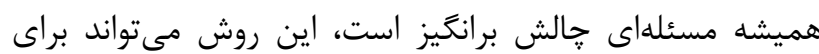

$$
\begin{aligned}
& \text { مطالعه روند رشد ساير قارجها نيز مفيد باشد. } \\
& \text { سياسگزן ارى } \\
& \text { بدينوسيله از تمام اساتيد محترم دانشكده علوم و فنون نوين } \\
& \text { دانشگاه تهران، ايران كه ما را يارى نمودند تشكر و قدردانى }
\end{aligned}
$$

8. Papinutti L. Effects of nutrients, $\mathrm{pH}$ and water potential on exopolysaccharides production by a fungal strain belonging to Ganoderma lucidum complex, Bioresour Technol., 2010; 101:1941-1946. [DOI:10.1016/j.biortech.2009.09.076] [PMID]

9. Zhao W, Xu J, Zhong J. Bioresource Technology Enhanced production of ganoderic acids in static liquid culture of Ganoderma lucidum under nitrogenlimiting conditions, Bioresour Technol., 2011; 102:8185-8190.

[DOI:10.1016/j.biortech.2011.06.043] [PMID]

10. Xu P, Ding ZY, Qian Z. Improved production of mycelial biomass and ganoderic acid by submerged culture of Ganoderma lucidum SB97 using complex media, Enzyme Microb Technol., 2008; 42:325-331. [DOI:10.1016/j.enzmictec.2007.10.016]

11. Zhang WX, Zhong JJ. Effect of oxygen concentration in gas phase on sporulation and individual ganoderic acids accumulation in liquid static culture of Ganoderma lucidum, J Biosci Bioeng., 2010; 109:3740. [DOI:10.1016/j.jbiosc.2009.06.024] [PMID]

12. Wei Z, Duan Y, Qian Y. Screening of Ganoderma strains with high polysaccharides and ganoderic acid contents and optimization of the fermentation medium by statistical methods, Bioprocess Biosyst Eng., 2014; 37: 1789-1797. [DOI:10.1007/s00449014-1152-2] [피]

13. Kirk TV, Szita N. Oxygen transfer characteristics of miniaturized bioreactor systems, Biotechnol Bioeng., 2013; 110:1005-1019. [DOI:10.1002/bit.24824] [PMID] [플

14. Wagner R, Mitchell DA, Sassaki GL. Current Techniques for the Cultivation of Ganoderma lucidum for the Production of Biomass, Ganoderic Acid and Polysaccharides, Food Technol. Biotechnol., 2003; 41:371-382.

15. Keypour S, Rafat H, Riahi H. Qualitative analysis of ganoderic acids in Ganoderma lucidum from Iran and China by RP-HPLC and electrospray ionisation-mass 
spectrometry (ESI-MS, Food Chem., 2010; 119:1704-1708.

[DOI:10.1016/i.foodchem.2009.09.058]

16. Heydarian MS, Hatamian-Zarmi A, Amoabediny G, Yazdian F, Doryab A. Synergistic Effect of Elicitors in Enhancement of Ganoderic Acid Production: Optimization and Gene Expression Studies. Applied food biotechnology. 2015; 2(3): 57-62.

17. Anderlei T, Zang W, Papaspyrou M, Büchs J. Online respiration activity measurement (OTR, CTR, RQ) in shake flasks, Biochem Eng J., 2004; 17:187-194. [DOI:10.1016/S1369-703X(03)00181-5]

18. Fang, QH, Zhong JJ. Submerged fermentation of higher fungus Ganoderma lucidum for production of valuable bioactive metabolites - Ganoderic acid and polysaccharide, Biochem Eng J., 2002; 10:61-65. [DOI:10.1016/S1369-703X(01)00158-9]

19. Tang YJ, Zhong JJ. Fed-batch fermentation of Ganoderma lucidum for hyperproduction of polysaccharide and ganoderic acid, Enzyme Microb Technol., 2002; 31:20-28. [DOI:10.1016/S01410229(02)00066-2]

20. Amoabediny G, Rezvani M, Rashedi H. Application of a novel method for optimization of bioemulsan production in a miniaturized bioreactor, Bioresour Technol., 2010; 101:9758-9764. [DOI:10.1016/j.biortech.2010.07.009] [PMID]
21. Amoabediny G, Ziaie-Shirkolaee $Y$, Büchs J. Development of an unsteady-state model for a biological system in miniaturized bioreactors, Biotechnol Appl Biochem., 2009; 54:163-170. [DOI:10.1042/BA20090141] [PMID]

22. Amoabediny G, Büchs J. Modelling and advanced understanding of unsteady-state gas transfer in shaking bioreactors, Biotechnol Appl Biochem., 2007; 46:57-67. [DOI:10.1042/BA20060120] [PMID]

23. $\mathrm{Xu} J W, \mathrm{Xu} Y \mathrm{YN}$, Zhong JJ. Production of individual ganoderic acids and expression of biosynthetic genes in liquid static and shaking cultures of Ganoderma lucidum, Appl Microbiol Biotechnol., 2010; 85:941948. [DOI:10.1007/s00253-009-2106-5] [PMID]

24. Livak KJ, Schmittgen TD. Analysis of relative gene expression data using real-time quantitative PCR and the 2(-Delta Delta C(T)) Method, Methods., 2001; 25: 402-408. [DOI:10.1006/meth.2001.1262] [PMID]

25. Ren A, Qin L, Shi L. Methyl jasmonate induces ganoderic acid biosynthesis in the basidiomycetous fungus Ganoderma lucidum, Bioresour Technol., 2010; 101:6785-6790. [DOI:10.1016/j.biortech.2010.03.118] [PMID] 